\title{
Review
}

\section{BCL-2 family proteins: changing partners in the dance towards death}

\author{
Justin Kale ${ }^{1}$, Elizabeth J Osterlund ${ }^{1,2}$ and David W Andrews ${ }^{\star, 1,2,3}$
}

The BCL-2 family of proteins controls cell death primarily by direct binding interactions that regulate mitochondrial outer membrane permeabilization (MOMP) leading to the irreversible release of intermembrane space proteins, subsequent caspase activation and apoptosis. The affinities and relative abundance of the BCL-2 family proteins dictate the predominate interactions between anti-apoptotic and pro-apoptotic BCL-2 family proteins that regulate MOMP. We highlight the core mechanisms of BCL-2 family regulation of MOMP with an emphasis on how the interactions between the BCL-2 family proteins govern cell fate. We address the critical importance of both the concentration and affinities of BCL-2 family proteins and show how differences in either can greatly change the outcome. Further, we explain the importance of using full-length BCL-2 family proteins (versus truncated versions or peptides) to parse out the core mechanisms of MOMP regulation by the BCL-2 family. Finally, we discuss how posttranslational modifications and differing intracellular localizations alter the mechanisms of apoptosis regulation by BCL-2 family proteins. Successful therapeutic intervention of MOMP regulation in human disease requires an understanding of the factors that mediate the major binding interactions between BCL-2 family proteins in cells.

Cell Death and Differentiation (2018) 25, 65-80; doi:10.1038/cdd.2017.186; published online 17 November 2017

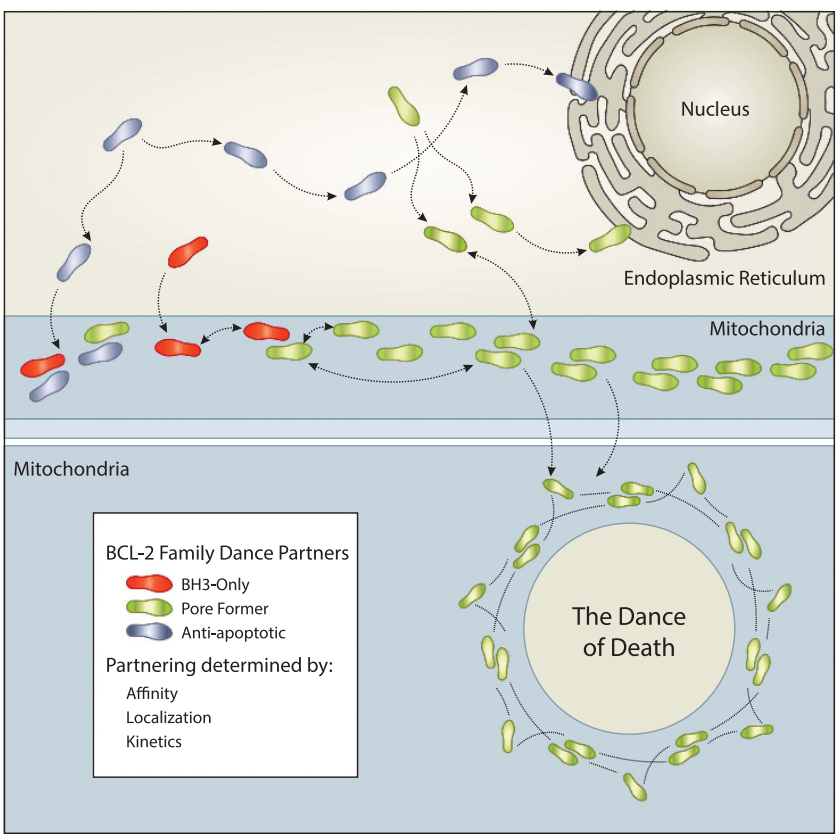

Graphical Abstract

- The membrane plays an active role in most BCL-2 family interactions by changing the affinities and local relative abundance of these proteins.

- The majority of studies examining the interactions between $\mathrm{BCL}-2$ family proteins use truncated proteins or peptides of the $\mathrm{BH} 3$ region at physiologically irrelevant concentrations or in the absence of membranes leading to confusion in defining the core mechanisms of the BCL-2 family proteins.

- Differential expression in various tissues, targeting to different subcellular localizations and post-translational modifications all contribute to regulation of BCL-2 family-binding interactions.

- Targeting the BH3 domain-binding groove of anti-apoptotic $\mathrm{BCL}-2$ family proteins with $\mathrm{BH} 3$ mimetics has proven useful in generating anti-cancer therapeutics but future improvements depend on accounting for more of the factors that govern BCL-2 family interactions.

\section{Questions:}

- Other than the $\mathrm{BH} 3$ region, which factors determine the dominant interactions between the BCL-2 family proteins?

- How do the affinities between, and physiologically relevant concentrations of, BCL-2 family proteins in cells dictate the regulation of apoptosis?

- How do BAX and BAK transition from inactive monomers to membrane-embedded oligomers that permeabilize membranes?

- Direct physical interactions between the BCL-2 family proteins dictated by BCL-2 homology $3(\mathrm{BH} 3)$ regions regulate mitochondrial outer membrane permeabilization (MOMP).

- How do BCL-2 family proteins control cell death at intracellular locations other than the mitochondria?

${ }^{1}$ Biological Sciences, Sunnybrook Research Institute, Toronto, ON, Canada; ${ }^{2}$ Department of Biochemistry, University of Toronto, Toronto, ON, Canada and ${ }^{3}$ Department of Medical Biophysics, University of Toronto, Toronto, ON, Canada

${ }^{*}$ Corresponding author: D Andrews, Biological Sciences, Sunnybrook Research Institute, 2075 Bayview Avenue, Toronto, ON, Canada. Tel: +416 480 5120 ; Fax: 416480 4375; E-mail: david.andrews@ sri.utoronto.ca

Received 11.7.17; revised 17.9.17; accepted 19.9.17; Edited by F Pentimalli; published online 17.11.17 


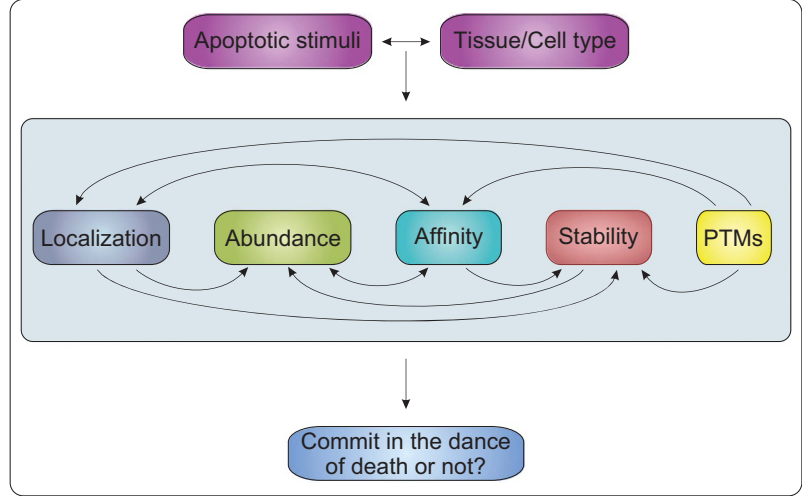

Figure 1 Cellular factors regulating commitment to the apoptotic dance of death by the BCL-2 family proteins. BCL-2 family proteins function by direct binding interactions that lead to mutual sequestration and/or membrane permeabilization. These direct protein-protein binding interactions are functionally regulated in cells by a number of interrelated processes. Differences in apoptotic stimuli and cell types lead to different responses due to the integration of the effects of localization, abundance, affinity, stability and post-translational modifications (PTMs). Related interactions are connected by arrows. For example, PTMs affect protein stability, localization and binding affinities. Affinities determine which interactions dominate but also affect localization and stability (heterodimerization with BH3-only proteins stabilizes MCL-1). The affinities of BCL-2 family proteins for intracellular membranes and other binding partners at these membranes dictate BCL-2 family localization. $\mathrm{Co}$ localization increases local concentrations (abundance). Protein stability also impacts abundance of the BCL-2 family proteins. The relative abundance and affinity ultimately determine which binding interactions dominate and whether or not the cell undergoes MOMP committing it to apoptosis

\section{Introducing the dance of death}

Dancing is a joy of life; however, cells have a dance between the BCL-2 family proteins that can lead to death. Exchange of dance partners within the BCL-2 family proteins regulates apoptosis. The outcome of this dance - the fate of the cell - is decided by the net interactions between the BCL-2 family proteins. These interactions are governed by the abundance of the proteins and the 'attraction' (affinity) between the partners. The affinities between the dance partners are the result of protein conformation changes, most of which occur on the dance floor - the intracellular membranes where the interactions between the BCL-2 family proteins take place. Further, the apoptotic stimuli, cell type and post-translational modifications differentially regulate the interactions that predominate to control MOMP. This concept of contextdependent regulation of apoptosis is outlined in Figure 1.

In one view, the ultimate goal of the dance between the $\mathrm{BCL}-2$ family proteins is to trigger apoptosis by forming pores within the mitochondrial outer membrane. MOMP results in the release of pro-apoptogenic factors (e.g., cytochrome $c$ ) from the mitochondrial intermembrane space (IMS) into the cytosol ultimately causing the activation of a caspase cascade that functions to dismantle and destroy the cell. ${ }^{1}$ Caspases cleave hundreds of proteins vital for proper cellular function and homeostasis culminating in the typical biochemical and morphological features of apoptosis. ${ }^{2}$

Commitment to the apoptotic dance of death is due in part to MOMP being rapid and complete - cytochrome $c$ is released from most mitochondria within 5 mins and complete caspase activation occurs within 15 minutes inevitably resulting in cell death. ${ }^{3-5}$ As BCL-2 family proteins regulate this critical cell fate decision an abundance of research has focused on understanding the interactions between the BCL-2 family proteins, the regulation of these interactions within a cell, and how these interactions lead to MOMP.

\section{Dancing on and within membranes - molecular mechanisms of BCL-2 family regulation}

The BCL-2 family is divided into three groups based on their primary function (1) anti-apoptotic proteins (BCL-2, BCL- $X_{L}$, BCL-W, MCL-1, BFL-1/A1), (2) pro-apoptotic pore-formers (BAX, BAK, BOK) and (3) pro-apoptotic BH3-only proteins (BAD, BID, BIK, BIM, BMF, HRK, NOXA, PUMA, etc.). All $\mathrm{BCL}-2$ family proteins contain a $\mathrm{BH}$ domain; one of four $\mathrm{BH}$ domains involved in interactions between these proteins. ${ }^{6}$ The anti-apoptotic and pore-forming proteins contain all four $\mathrm{BH}$ domains (multi-BH domain proteins) and adopt a highly conserved tertiary structure forming a hydrophobic $\mathrm{BH} 3$ domain-binding groove that acts as a receptor for $\mathrm{BH} 3$ domains of other family members. ${ }^{7}$ The $\mathrm{BH} 3$-only proteins are subdivided into activator and sensitizer proteins, which contain only the $\mathrm{BH} 3$ domain and with the exception of BID are unstructured in solution, reviewed in ref. 8 . With the stage set and the dancers named, who 'dances' with whom dictates whether or not MOMP occurs.

Various competing models (reviewed in ref. 9) describe how BCL-2 family proteins interact with each other to control MOMP. Figure 2 highlights the 'embedded together' model that puts an emphasis on the role of the membrane as the 'locus of action' for most BCL-2 family proteins. ${ }^{10}$ In all models, the $\mathrm{BH} 3$ domain is necessary for the primary apoptotic function of BCL-2 family members and the interactions between them at intracellular membranes. The $\mathrm{BH}$ domain of activator $\mathrm{BH}$ only proteins binds to the $\mathrm{BH} 3$ domain-binding groove in $\mathrm{BAX} /$ BAK. ${ }^{11,12}$ This activates BAX and BAK, eliciting a series of conformation changes that result in BAX/BAK homooligomerization and pore formation within the MOM (Figure 2b). The $\mathrm{BH} 3$ domain-binding groove in antiapoptotic proteins binds the $\mathrm{BH} 3$ domains of the poreformers and the activator $\mathrm{BH} 3$-only proteins, inhibiting their function by sequestering them (Figure 2c). ${ }^{13,14}$ The $\mathrm{BH} 3$ domain of sensitizer $\mathrm{BH} 3-$ only proteins binds to the $\mathrm{BH} 3$ domain-binding groove of anti-apoptotic proteins, inactivating them. ${ }^{15}$ This interaction is competitive with binding of activator $\mathrm{BH} 3-$ only proteins and pore-formers leading to their displacement from anti-apoptotic proteins (Figures $2 \mathrm{~d}$ and e). Many, if not most, of these interactions occur at, on and within the MOM. ${ }^{16}$ The lipid bilayer has an active role in facilitating structural changes of the BCL-2 family proteins that alter their affinities and consequently the interactions between them thus governing whether or not MOMP occurs. ${ }^{17}$

The embedded together model is more complicated than the original rheostat model that proposed apoptotic fate is determined by the ratio of pro-apoptotic to pro-survival proteins in a cell. ${ }^{18}$ The rheostat model was conceived when the BCL-2 family consisted of BCL-2 and BAX and posited that the more abundant protein decided life versus death, respectively. In the context of the more complicated interactions between the expanded families of BCL-2 proteins the 
basic posit of the rheostat model remains relevant. Ultimately, the fate of the cell is decided by the interactions between the BCL-2 family dancers. The interactions are determined by the relative abundance and affinities of the partners. Both are impacted by the affinity for membranes, which regulates the localization, conformation and therefore, function of BCL-2 family members. However, similar to the rheostat model, if the sum of interactions results in BAX/BAK oligomers and MOMP - then the cell is committed to death and will dance no more.

\section{Attraction among the BCL-2 family proteins dictates dance partners}

Understanding the primary interactions that occur between the BCL-2 family members requires knowledge of the affinity and concentration of each member. These factors dictate the predominate interactions and thus if MOMP occurs. The consequences of differing affinities between the BCL-2 family proteins can be illustrated with a simple case of binding competition between CBID, BCL-X $X_{L}$ and BAX. We have previously demonstrated that $B C L-X_{L}$ functions as a dominant negative $B A X .^{19}$ When $C B I D, B C L-X_{L}$ and $B A X$ were incubated together, $B A X-m e d i a t e d$ membrane permeabilization was completely inhibited. If a mutant of cBID that interacts with BAX but not BCL- $X_{L}$ was used, BAX-mediated membrane permeabilization was not inhibited to the same extent. This suggests that $C B I D$ preferentially interacts with $B C L-X_{L}$ over $B A X$. Using purified full-length recombinant $B A X, B C L-X_{L}$ and cBID we have found that the affinity (dissociation constant, $K_{D}$ ) between BCL- $X_{L}$ and $C B I D$ is $3 \mathrm{nM}$ (unpublished data), whereas the affinity between $C B I D$ and $B A X$ is high micromolar in the absence and $25 \mathrm{nM}$ in the presence of membranes. ${ }^{20}$ The interaction between $\mathrm{CBID}$ and BAX in the absence and presence of $B C L-X_{L}$ can be modeled using these $K_{D}$ values (Figure $3 a){ }^{21}$ The higher affinity of $C B I D$ for $B C L-X_{L}$ versus that of $B A X$ prevents $B A X$ activation and only a supraphysiological concentration of BAX can out-compete BCL- $X_{L}$ for cBID binding. This simple example does not account for interactions between $B A X$ and $B C L-X_{L}$, the differing affinities of the proteins for membranes, changing conformations within the bilayer or the addition of sensitizer $\mathrm{BH} 3$-only proteins like BAD. The situation becomes more complex in cells where BCL-2 family proteins interact with known and unknown binding partners at different subcellular locations. Transcriptional and post-translational control of the BCL-2 family proteins further changes the abundance and affinities of these proteins modifying their interactions and localizations within the cell. These factors result in a complex interaction network, the sum of which determines cellular fate.

The first step in understanding the BCL-2 family interaction network is to establish the affinities between binding partners. The reported affinities of known BCL-2 family protein interactions are summarized in (Tables $1 \mathrm{~A}$ and $1 \mathrm{~B}$ ). Most of the affinity data were generated with $\mathrm{BH} 3$ peptides and c-terminally truncated multi-BH domain proteins. Organizing this affinity data by $\mathrm{BH} 3$ peptide length in Tables $1 \mathrm{~A}$ and $1 \mathrm{~B}$, revealed a distressing trend. The length of $\mathrm{BH} 3$ peptides used in the literature varies from 16 amino acids to $>30$. As observed for $\mathrm{BAK}$, and $\mathrm{BAD}$, the $\mathrm{BH} 3$ peptide length can have a large effect on the measured affinity. ${ }^{22,23}$ Adding to the confusion, different peptide lengths are often used for $\mathrm{BH} 3-$ only proteins within the same paper. $^{24,25}$ Generally, BH3 peptide length correlates with increased affinity for the binding partner suggesting that residues outside of the $\mathrm{BH} 3$ domain facilitate proper interactions among BCL-2 family proteins. ${ }^{26}$ This summary found BIM to be the most studied $\mathrm{BH} 3$ peptide but also revealed a scarcity in studies that measure affinities for BAX or BAK binding. In fact, little data have been reported for many of the $\mathrm{BH} 3$ proteins including BAP31, BCL-B, BCL-G, BCL-RAMBO, BCL-W, BECLIN-1, BFK, BFL-1/A1, BOK and SPIKE binding to multi-BH domain proteins.

To understand the reported affinities in a cellular context, the physiologically relevant concentration ranges for BCL-2 family proteins must be known. It is frequently stated that cellular concentrations of BCL-2 family proteins are in the low nanomolar range. However, with the exception of BAX, with endogenous levels reported between $3 \mathrm{nM}$ and $170 \mathrm{nM}$, it appears that the low nanomolar statements are not well supported by data. ${ }^{27,28}$ Direct measurement of concentrations in cells is highly desirable as the affinities between full-length BCL-2 family proteins are in the low nanomolar range. Thus, the micromolar dissociation constants measured using peptides could be irrelevant if other BCL-2 family protein concentrations are in the low nanomolar range like BAX.

Studies with full-length proteins can reveal physiologically relevant interactions previously overlooked owing to the use of peptides. For example, many studies state that NOXA binds MCL-1 and BFL-1/A1 but does not bind BCL-2, BCL- $X_{L}$ or BCL-W, whereas BAD binds BCL-2, BCL- $X_{L}$ and BCL-W but not MCL-1 or BFL-1/A1. ${ }^{29,30}$ This matches well with the reported affinities for NOXA and $B A D$ peptides binding truncated anti-apoptotic proteins (Tables $1 \mathrm{~A}$ and 1B). NOXA has nanomolar affinity for MCL-1 and BFL-1/A1 and micromolar affinity (which may not be relevant physiologically) with $B C L-2, B C L-X_{L}$ or $B C L-W$, whereas $B A D$ is the reverse. However, these affinities and binding specificities change when full-length proteins are used. Full-length NOXA bound with dissociation constants of $3.4 \mathrm{nM}$ for MCL-1, $70 \mathrm{nM}$ for $B C L-X_{L}$ and $250 \mathrm{nM}$ for BCL-2, demonstrating full-length NOXA binding selectivity but not specificity. ${ }^{31}$ Consistent with these affinities, NOXA and BCL-2 interactions contributed to drug resistance in lymphoid cells suggesting that BCL-2 can prevent NOXA-mediated apoptosis. ${ }^{31}$

Most methods used to measure protein-protein interactions between BCL-2 family proteins neglect the influence of membranes. For example, full-length CBID and BAX interact in the presence of lipid membranes but not in solution because cBid requires a conformation change at membranes to interact with and activate $\mathrm{BAX}{ }^{17,20} \mathrm{~A}$ complete map of these interactions with affinities of full-length proteins in solution and in membranes will be essential to the delineation of the interactions between $\mathrm{BCL}-2$ family proteins that regulate cell death.

\section{Defining roles in the dance - what factors make a $\mathrm{BH} 3-$ only protein an activator?}

BH3-only proteins are classified as activator or sensitizer proteins based on whether or not they bind to and activate $\mathrm{BAX}$ and BAK. Activator BH3-only proteins promote MOMP 


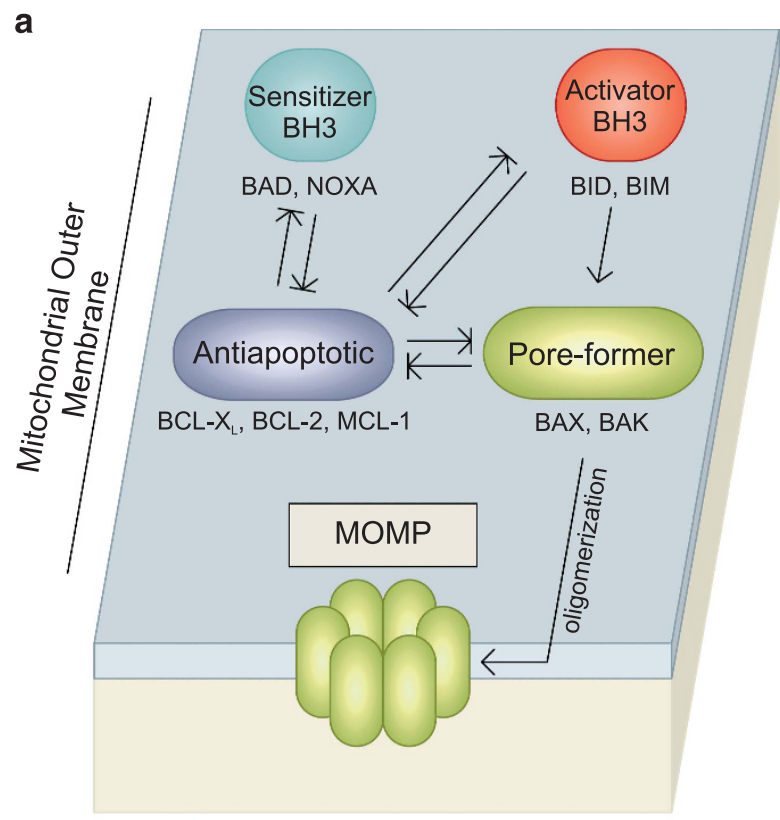

b

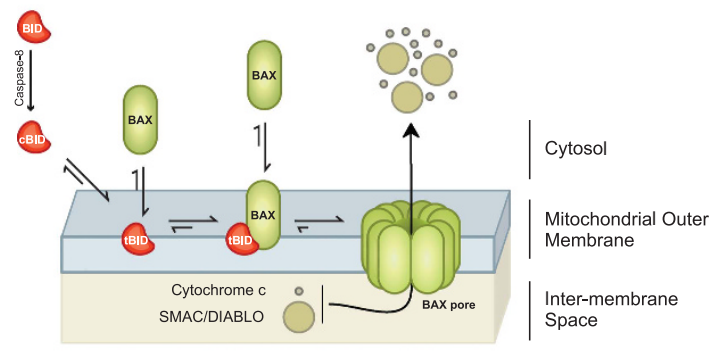

C

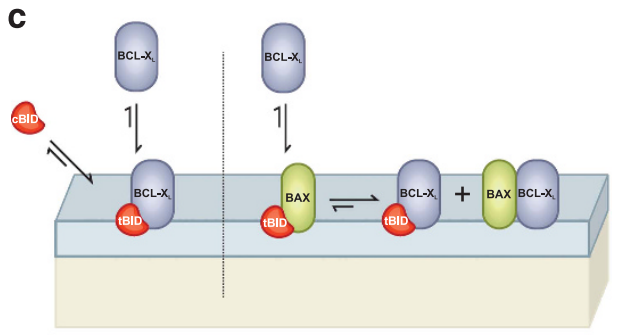

d

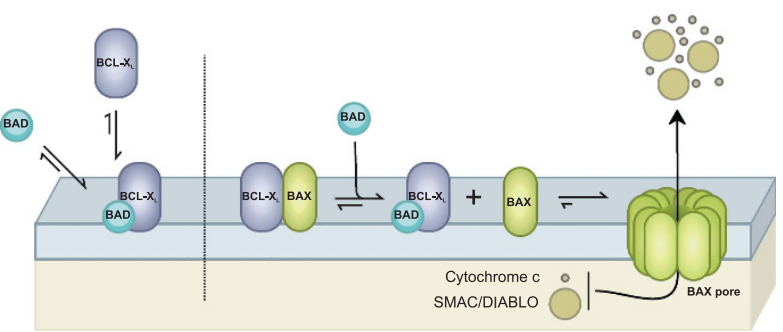

e

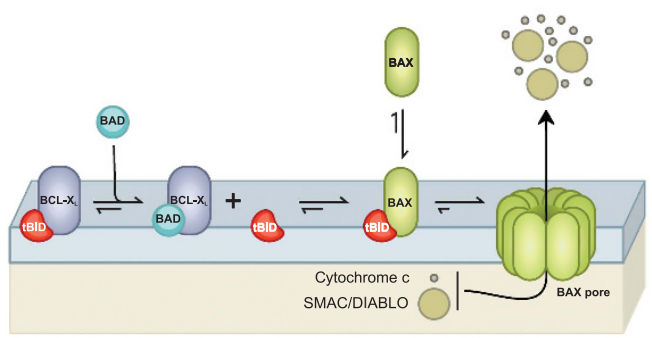

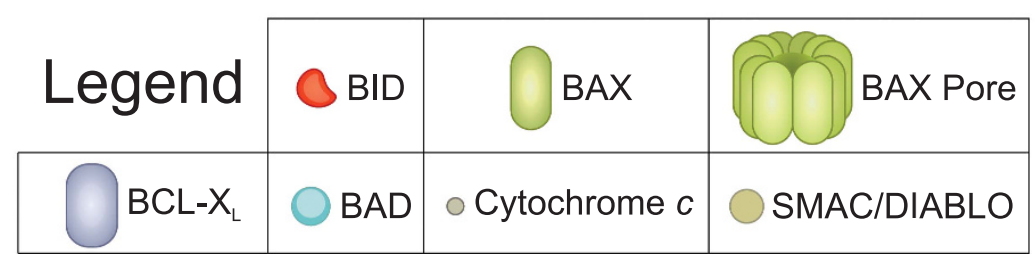

directly by triggering oligomerization of $\mathrm{BAX}$ and $\mathrm{BAK}$. In contrast, sensitizer BH3-only proteins promote MOMP indirectly via binding to and inhibiting the anti-apoptotic proteins. However, activator BH3-only proteins bind both BAX and BAK and anti-apoptotic proteins. Furthermore, binding of an activator $\mathrm{BH}$-only protein to an anti-apoptotic protein also inhibits the anti-apoptotic protein. Therefore, who is inhibiting whom, comes down to the relative abundance and affinities between activator $\mathrm{BH} 3-$ only proteins and antiapoptotic proteins. This redefines the interaction between activators and anti-apoptotic proteins as 'mutual sequestration', whereby $\mathrm{BH} 3-$ only proteins bind to and inhibit antiapoptotic proteins and vice versa. ${ }^{9}$ Furthermore, activator BH3-only proteins promote the membrane-embedded 
Figure 2 The dance of the BCL-2 family within the bilayer regulates mitochondrial outer membrane permeabilization (MOMP) and apoptosis (a) Schematic of the embedded together model. All binding interactions are reversible and equilibria are governed by local affinities. Interactions with the lipid bilayer change the affinities of the interactions and therefore have an active role in the functions of the proteins. Binding of the activator BH3-only proteins (e.g., BID, BIM) to membranes increases their affinity for the pore-formers (e.g. BAX, BAK), which are activated (arrows) to permeabilize the mitochondrial outer membrane. The anti-apoptotic proteins (e.g., BCL- $X_{L}$, BCL-2, MCL-1) inhibit both the activator BH3-only proteins and the pore-forming proteins by mutual sequestration (T'd arrows). The sensitizer BH3-only proteins (e.g., BAD, NOXA) bind to and inhibit the antiapoptotic proteins also by mutual sequestration. Recruitment of the complexes to the membrane by constitutive interactions (e.g., BAK) and dynamic interactions (e.g., BAX, BID, BIM) increases the affinities and local concentrations and reduces the diffusion of the BCL-2 family proteins. Localization at different intracellular membranes also dictates the binding equilibria between each family member. The efficiency of inhibition by mutual sequestration of anti-apoptotic proteins depends on both affinities and off-rates of the interactions. Interaction of the BH4 region of the anti-apoptotic proteins with BAX shifts the BAX-membrane binding equilibrium to favor the unbound state (retrotranslocation, not shown). (b-d). Interactions of the BCL-2 family that promote or inhibit MOMP illustrated for CBID. BAX, BCL- $X_{L}$ and BAD as examples of different functional categories. (b) BID is activated by caspase-8 mediated cleavage to cBID (cleaved BID) a protein comprised of two fragments BID-P7 and BID-P15 held together by hydrophobic interactions. Rapid high-affinity binding to membranes dissociates the p7 fragment to solution and favors insertion of the p15 fragment (tBID; truncated BID) into the membrane. Membrane-bound $\mathrm{tBID}$ recruits inactive BAX from the cytosol. Binding to tBID activates BAX to insert in the bilayer, oligomerize and permeabilize the mitochondrial outer membrane releasing intermembrane space proteins including cytochrome $c$ and SMAC. (c) Active $\mathrm{BIID}$ and BAX can recruit BCL- $\mathrm{X}_{\mathrm{L}}$ to the membrane resulting in inhibition of both pro and antiapoptotic proteins by mutual sequestration. BCL- $X_{L}$ prevents $B C L-X_{L}$ is in the active (oligomerization competent) conformation. (d, e) BAD inhibits unbound BCL- $X_{L}$ by mutual sequestration. The affinity of $B C L-X_{L}$ is higher for tBID than for active BAX (Tables $1 A$ and $1 B$ ) therefore, in the absence of other regulatory interactions or PTMs if BCL- $X_{L}$ is bound to $t B I D$ and $B A X$ then high concentrations of BAD will displace active $B A X(d)$ and then $\mathrm{BID}(\mathbf{e})$ from $B C L-X_{L}$ resulting in MOMP

conformation of anti-apoptotic proteins and thus also 'activate' these proteins. ${ }^{19}$ As a result a $\mathrm{BH}$-only protein with lower affinity for the membrane-bound form of an anti-apoptotic protein may function primarily to activate it. At high relative concentrations activator $\mathrm{BH} 3$-only proteins are expected to inhibit anti-apoptotic proteins while also activating BAX/BAK. For example, mutants of both BIM and BID that cannot bind BAX but can bind anti-apoptotic proteins promote apoptosis by functioning as sensitizer BH3-only proteins. ${ }^{32-34}$ Similarly, specific mutations to the $\mathrm{BH} 3$ domains of sensitizer $\mathrm{BH}$-only proteins BAD and NOXA turn these proteins into direct BAX activators without abrogating interactions with $\mathrm{BCL}-\mathrm{X}_{\mathrm{L}} \cdot{ }^{12}$ Therefore, an activator BH3-only protein is a sensitizerprotein that has gained an additional dance partner aiding in the dance of death through activation of BAX or BAK.

Does the capacity to bind and activate pore-formers constitute the 'activator' classification of a BH3-only protein? Many $\mathrm{BH} 3$ peptides bind both anti-apoptotic proteins and poreformers owing to the similarity between the $\mathrm{BH} 3$ domain-binding grooves. For example, the BH3 sensitizer NOXA primarily targets MCL-1 with an affinity of $3.4 \mathrm{nM}$. $^{31}$ However, both NOXA and the bona fide activator $\mathrm{BH}, \mathrm{BID}$ can activate $\mathrm{BAX}$ to permeabilize membranes in vitro, causing NOXA to be classified as an activator BH3-only protein in some reports. $^{35,36}$ This confusion is cleared up by examining affinities; the affinity of BID to BAX is $25 \mathrm{nM}$, whereas the affinity of NOXA to $\mathrm{BAX}$ is 1000 times higher $(25 \mu \mathrm{M})$ (Figure $3 b)$. BAX can be activated by NOXA, however, physiologically irrelevant micromolar concentrations are required. Therefore, the capacity to bind and activate pore-formers at physiologically relevant concentrations defines a $\mathrm{BH} 3-o n l y$ protein as an activator.

The question now is: what confers activator function and an increased affinity to BAX/BAK for full-length $\mathrm{BH} 3$-only proteins compared with peptides? The $\mathrm{BH} 3$ domain has a significant role in determining binding affinity, and mutations to the $\mathrm{BH} 3$ domains of BID and BIM fully abrogate their activator function. ${ }^{12}$ However, the $\mathrm{BH} 3$ domain is not the only portion of the protein promoting BAX/BAK activation. Low nanomolar $(<10 \mathrm{nM})$ concentrations of recombinant full-length BID or BIM activate BAX in vitro, whereas micromolar concentrations of $\mathrm{BH} 3$ peptides are needed to achieve the same level of $\mathrm{BAX}$ activation. ${ }^{37}$ The creation of SAHBs (Stabilized Alpha-Helices of BCL-2 domains) highlighted the importance of $\mathrm{BH} 3$ domain secondary structure. ${ }^{38}$ SAHB peptides are forced into a tight alpha helical structure through a 'staple' - a covalent bond between two regions of the peptide. SAHBs of BID and BIM are more efficacious in BAX activation compared with their 'unstapled' $\mathrm{BH} 3$ peptides but still require $200-600 \mathrm{nM}$ concentrations to fully activate $\mathrm{BAX} \cdot{ }^{39,40}$ Thus, an alpha helical $\mathrm{BH} 3$ domain is not enough for full efficacy.

High nanomolar concentrations of helical $\mathrm{BH} 3$ domain peptides may be required because the peptides do not bind to membranes as do $\mathrm{CBID}$ and $\mathrm{BIM}{ }^{41-43}$ Tethering a BID BH3 peptide, or a BID SAHB to the membrane resulted in efficient BAX activation at low nanomolar concentrations albeit with slower membrane permeabilization kinetics compared with fulllength tBID. ${ }^{40,44}$ Membrane targeting of the BID BH3 peptide increases the alpha-helicity of the $\mathrm{BH} 3$ domain such that the peptide activates BAX as efficiently as a membrane-targeted SAHB. ${ }^{40,44}$ This indicates two things (1) binding to membranes increases the alpha-helicity of the $\mathrm{BH} 3$ domain increasing affinity for BAX and (2) membrane binding likely increases the activity of these peptides by increasing the local concentration of the peptide resulting in more efficient BAX activation. However, membrane-targeted peptides are still 5-10 times less efficacious at activating BAX compared with full-length proteins, suggesting other regions outside the $\mathrm{BH} 3$ domain increase the affinity between activator $\mathrm{BH}$-only proteins and $\mathrm{BAX} / \mathrm{BAK}^{40}$

\section{The dance steps of the pore-formers - mechanisms of BAX/BAK-mediated MOMP}

The BAX and BAK activation mechanism is a multi-step dance within the bilayer. We and others have delineated steps in the BAX/BAK activation pathway that are generally agreed upon. ${ }^{20,45-47}$ Activator $\mathrm{BH} 3-$ only proteins contribute to recruitment of BAX to membranes, activating BAX/BAK monomers, which then undergo a substantial conformation change and embed within the bilayer. Activated BAX/BAK monomers form symmetric homodimers that oligomerize to form pores within the bilayer resulting in MOMP. Understanding these steps is imperative because each represents an opportunity for therapeutic intervention in human disease. Several studies have focused on determining the exact conformations of inactive and 


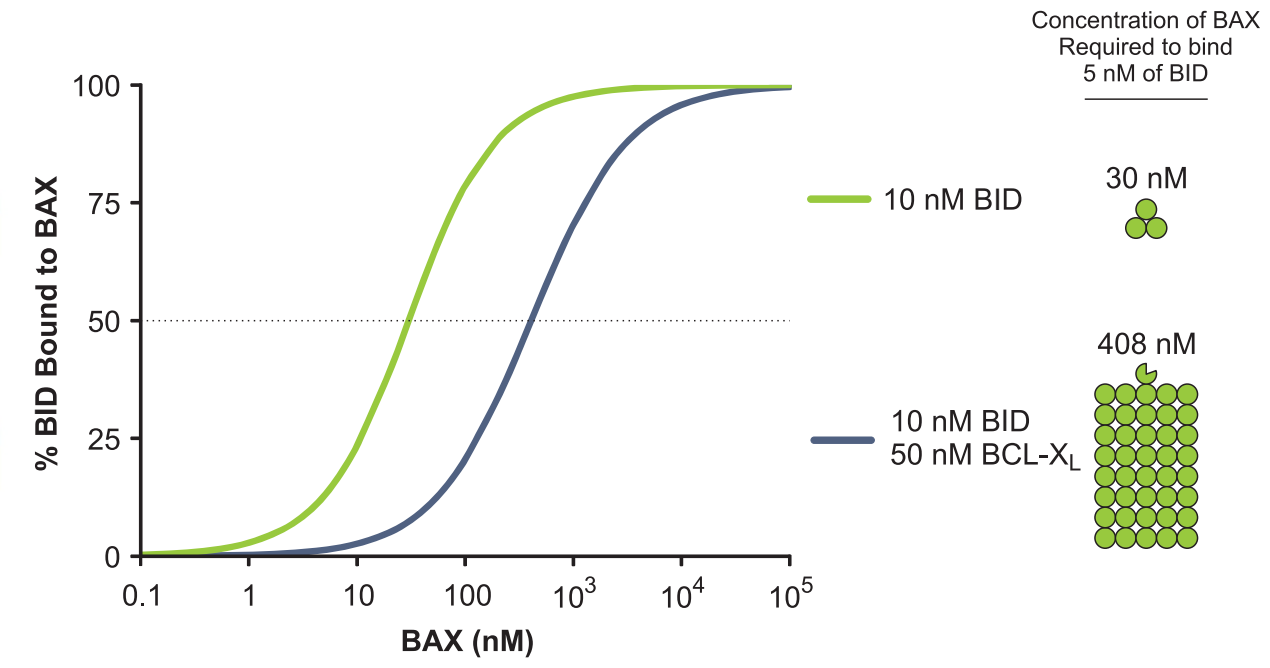

b
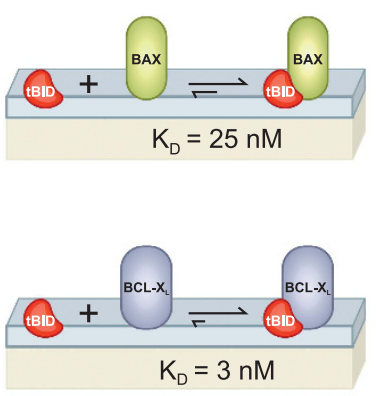

$10 \mathrm{nM}$ BID

$50 \mathrm{nM} \mathrm{BCL-} \mathrm{XL}_{\mathrm{L}}$
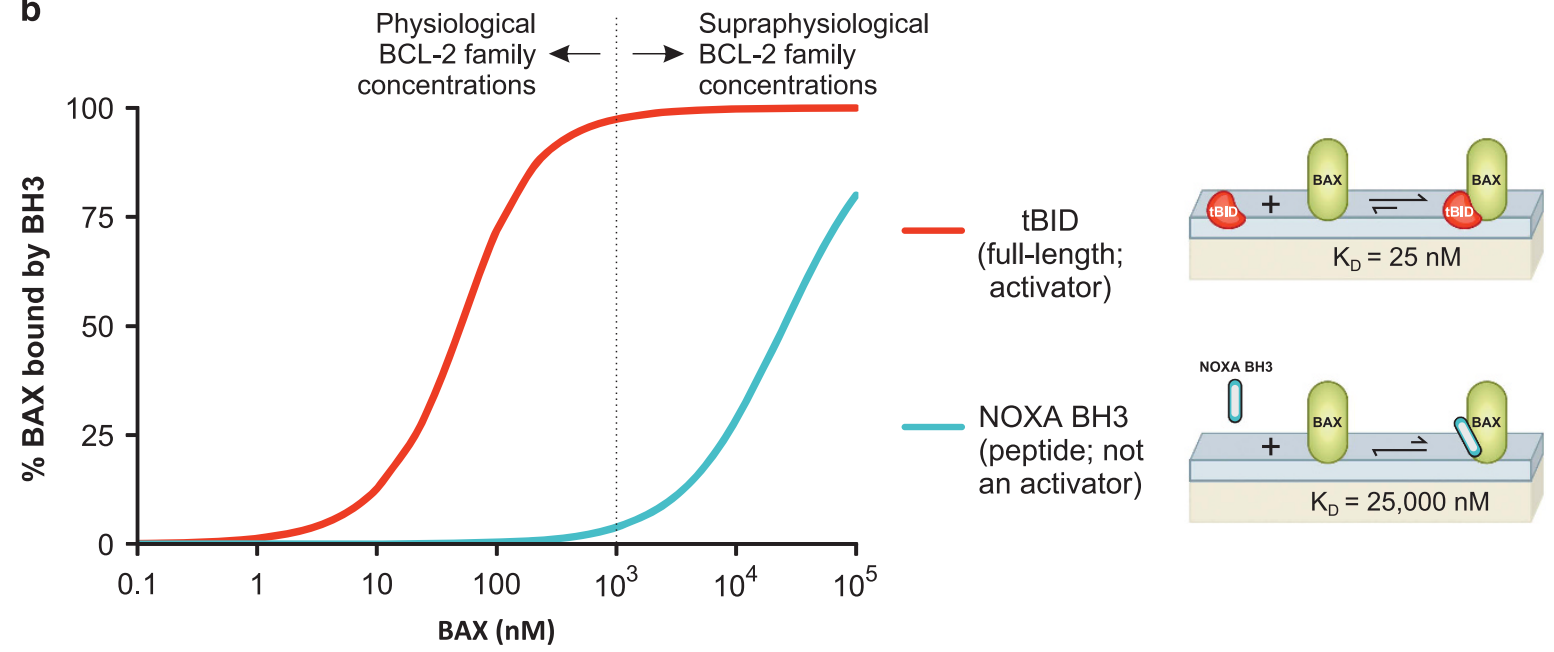

Figure 3 Affinities and concentrations dictate the predominate interactions of the BCL-2 family members (a) At membranes $C B I D$ binds $B A X$ and BCL-X with an affinity of $25 \mathrm{nM}$ and $3 \mathrm{nM}$, respectively. Equations describing competitive binding of two different 'ligands' (BAX, BCL- $\mathrm{X}_{\mathrm{L}}$ ) to one protein molecule (cBID) ${ }^{21}$ were used to model the Interaction of $10 \mathrm{nM} \mathrm{cBID}$ with increasing concentrations of BAX in the absence (green) and presence (purple) of $50 \mathrm{nM} \mathrm{BCL-} \mathrm{X}_{\mathrm{L}}$. In the absence of $\mathrm{BCL}-\mathrm{X}_{\mathrm{L}}, 50 \%$ of $10 \mathrm{nM} \mathrm{cBID}$ is bound to $\mathrm{BAX}$ at a $\mathrm{BAX}$ concentration of $30 \mathrm{nM}$. Upon the addition of $\mathrm{BCL}-\mathrm{X}_{\mathrm{L}}, \sim 13$ times more $\mathrm{BAX}$ ( $408 \mathrm{nM}$ ) is required to bind $50 \%$ of the $c B I D$. In this case, $\mathrm{BCL}-\mathrm{X}_{\mathrm{L}}$ is binding the majority of the $C B I D$, preventing $B A X$ activation. The functional consequence of the differing affinities results in $B C L-X$ out-competing $B A X$ for binding to $C B I D$, effectively inhibiting apoptosis at physiologically relevant concentrations of $B A X$. (b) The affinities between BH3-only proteins and $B A X$ determine whether a BH3-only protein functions as an activator or sensitizer. Equations describing the binding of two protein ${ }^{21}$ were used to model the interaction of $50 \mathrm{nM} \mathrm{BAX}$ with increasing concentrations of the indicated BH3only protein/peptide; full-length tBID (red) and NOXA BH3 peptide (cyan). The affinities of full-length tBID or NOXA BH3 peptide for BAX are $25 \mathrm{nM}{ }^{20}$ and $25000 \mathrm{nM}$ (estimated from ref. 35) respectively. Typical in vitro BAX activation assays use peptide concentrations in the micromolar range, well above the nanomolar concentrations predicted for BCL-2 family proteins in cells. At supraphysiological concentrations (>1000 nM) of peptides (e.g., NOXA, cyan) some BH3 sequences that typically function as sensitizers can bind to and activate BAX

active BAX/BAK, how their affinities for BCL-2 family proteins change and the transitions between conformations that occur for BAX/BAK to elicit MOMP. Despite years of examination, the complex mechanism is not fully understood partly owing to the difficulties in studying membrane-embedded proteins.

The specifics of BAX/BAK conformations during their activation and how they form pores have been reviewed recently. ${ }^{45,47}$ Rather than re-examine the precise conformations of BAX/BAK we will highlight some assumptions and unknowns regarding these models and how steps are regulated by changes in binding partners, affinities and conformations within the bilayer (Figure 4).
Activator BH3-only proteins start the dance of death by interacting with BAX/BAK at the bilayer. Activator $\mathrm{BH} 3-$ only proteins interact with BAX/BAK at the bilayer owing to the high affinity of activator $\mathrm{BH} 3$-only proteins for membranes (Figure 4; step 1). For BAK, it is obvious that this interaction occurs at the bilayer because BAK is constitutively localized to the MOM. However, many models assume that BAX interacts with activator $\mathrm{BH} 3$-only proteins in solution resulting in a soluble activated BAX that then inserts into the MOM. ${ }^{47-49}$ The data supporting interactions between activator $\mathrm{BH} 3$-only proteins and $\mathrm{BAX}$ in solution are from experiments using truncated $\mathrm{BAX}, \mathrm{BH} 3$ peptides or 
Table 1A BCL-2 family interactions; dissociation constants reported for BH3 peptides, truncated and full-length proteins

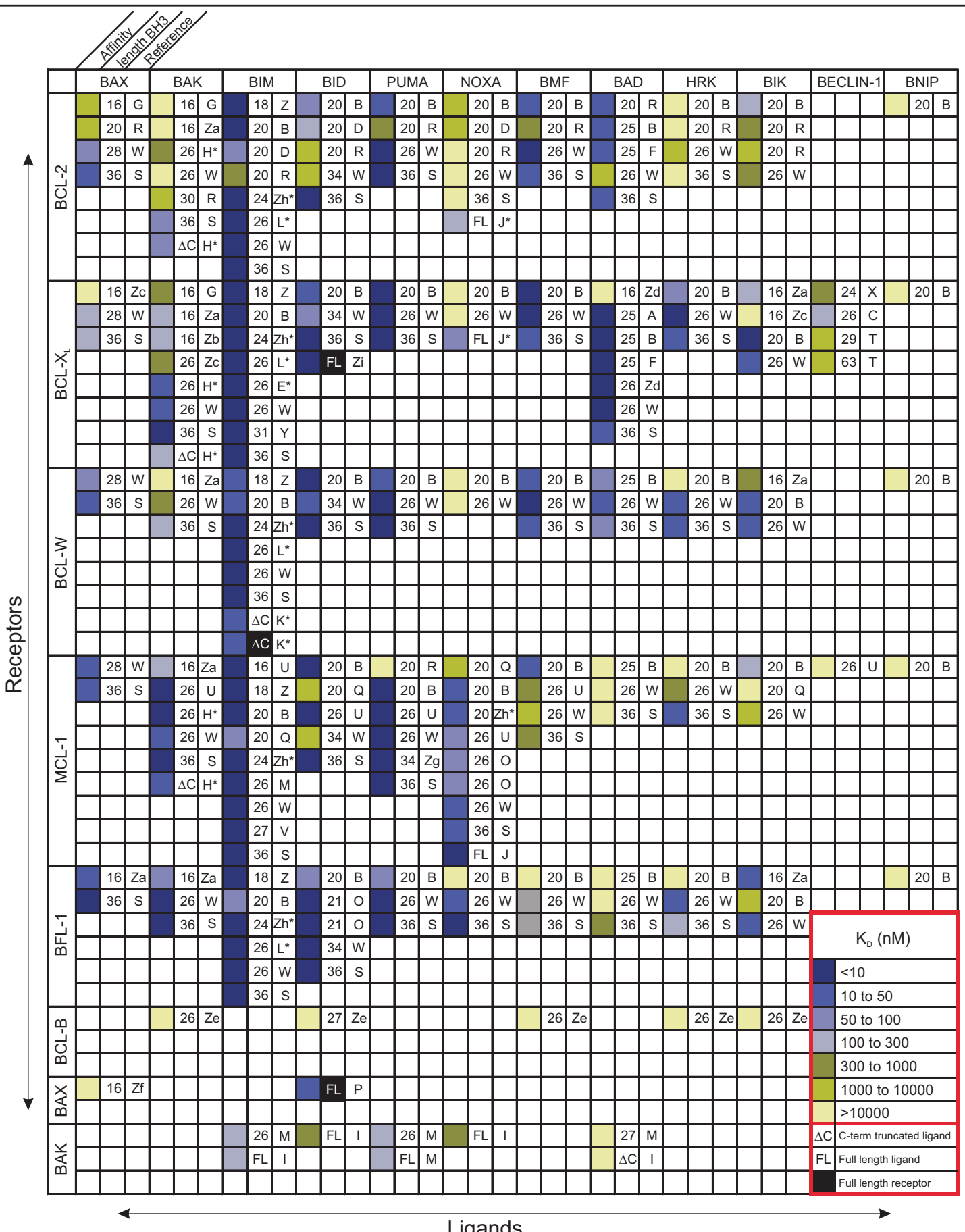

The affinity of a protein interaction is generally reported as a dissociation constant $\left(\mathrm{K}_{\mathrm{D}}\right)$. Unless otherwise specified, $\mathrm{K}_{\mathrm{D}}$ values obtained from the literature are for interactions between truncated multi-BH region protein 'receptors' (rows) and the corresponding BH3 'ligand' (columns). For each $\mathrm{BH} 3$ ligand, the first column indicates the $\mathrm{K}_{\mathrm{D}}$ represented on a color scale (legend bottom right of chart). The second column indicates the length of the $\mathrm{BH} 3$ peptide used. ' $\Delta \mathrm{C}$ ' represents a BH3-only protein lacking its C-terminal tail anchor and 'FL' indicates full-length BH3-only protein. Use of a full-length multi-BH region protein 'receptor' is indicated by black shading in the second column. The letter in the third column indicates the PMID and method, listed in B. For each interaction, $\mathrm{K}_{\mathrm{D}}$ values were sorted by peptide length (increasing length downward across rows). A reference with an asterisk (*) indicates the original report indicated that detergent was present when the $\mathrm{K}_{\mathrm{D}}$ was measured 
Table 1B PubMed ID number and method used to measure the $K_{D}$ values listed in $\mathrm{A}$

\begin{tabular}{|c|c|c|}
\hline Label & PMID & Method \\
\hline $\begin{array}{l}\text { A } \\
B \\
C \\
D \\
E \\
F \\
G\end{array}$ & $\begin{array}{l}11206074 \\
16697956 \\
17446862 \\
12242151 \\
19748896 \\
11248023 \\
11904405\end{array}$ & Fluorescence polarization (FP) \\
\hline $\begin{array}{l}\mathrm{H} \\
\mathrm{I} \\
\mathrm{J} \\
\mathrm{K} \\
\mathrm{L} \\
\mathrm{M}\end{array}$ & $\begin{array}{l}19351886 \\
21727192 \\
21454712 \\
12660157 \\
15694340 \\
24265320\end{array}$ & Surface plasmon resonance (SPR) \\
\hline $\mathrm{N}$ & 22156224 & SPR and time-resolved (TR)-FRET \\
\hline $\mathrm{O}$ & 21395401 & \\
\hline$P$ & 19062087 & Forster resonance energy transfer (FRET) \\
\hline $\begin{array}{l}Q \\
R \\
S \\
T \\
U \\
V \\
W \\
X\end{array}$ & $\begin{array}{l}20392693 \\
23996493 \\
21060336 \\
17337444 \\
18589438 \\
17389404 \\
28411240 \\
18641390\end{array}$ & Isothermal titration calorimetry (ITC) \\
\hline $\begin{array}{l}Y \\
Z\end{array}$ & $\begin{array}{l}20363230 \\
23363053\end{array}$ & Yeast surface display \\
\hline $\begin{array}{l}\mathrm{Za} \\
\mathrm{Zb}\end{array}$ & $\begin{array}{l}21713285 \\
19766123\end{array}$ & Bacterial surface display \\
\hline $\begin{array}{l}\mathrm{Zc} \\
\mathrm{Zd}\end{array}$ & $\begin{array}{l}9020082 \\
9372935\end{array}$ & Tryptophan fluorescence quenching \\
\hline $\begin{array}{l}\mathrm{Ze} \\
\mathrm{Zf}\end{array}$ & $\begin{array}{l}23192964 \\
24434006\end{array}$ & NMR spectroscopy \\
\hline $\begin{array}{l}\mathrm{Zg} \\
\mathrm{Zh} \\
\mathrm{Zi}\end{array}$ & $\begin{array}{l}23301700 \\
25052212 \\
27108441\end{array}$ & $\begin{array}{l}\text { Stopped flow technique } \\
\text { Fluorescence anisotropy } \\
\text { FRET }\end{array}$ \\
\hline
\end{tabular}

detergents that promote the conformational changes of $\mathrm{BAX}$ that normally occur at a lipid bilayer. Indeed, activator $\mathrm{BH} 3$ peptides remain in solution when binding to BAX/BAK, however, micromolar amounts of activator are required to fully activate BAX/BAK with slow membrane permeabilization kinetics compared with activation with full-length activator BH3-only proteins. ${ }^{37,40}$ In comparison, full-length activator $\mathrm{BH} 3-$ only proteins have a high affinity for membranes and efficiently activate BAX/BAK at nanomolar concentrations resulting in rapid membrane permeabilization kinetics. ${ }^{20,35,37,40}$ Activator $\mathrm{BH} 3-$ only proteins bind membranes (half-time $<50 \mathrm{~s}$ ) before interacting with BAX (halftime $\approx 500 \mathrm{~s}) .{ }^{50}$ Furthermore, activator BH3-only proteins require membrane binding for efficient $\mathrm{BAX} / \mathrm{BAK}$-mediated membrane permeabilization in vitro and in cells. ${ }^{20,41,51}$ Thus, binding between activator $\mathrm{BH}$-only proteins and BAX/BAK in solution may reflect what can happen with these proteins but in cells the relevant interactions occur at and within intracellular membranes.

Inviting BAX and BAK to dance without activator $\mathrm{BH}$ only proteins. BAX or BAK can be activated by antibodies, ${ }^{52}$ small molecules, ${ }^{53,54}$ heat, ${ }^{55} \mathrm{pH}^{56}$ detergents ${ }^{57-59}$ and metabolites, ${ }^{60}$ suggesting that all of the information for oligomerization and pore formation is contained within BAX and BAK. Thus, spontaneous activation of BAX/BAK could occur due to any perturbation of their compact globular structure that results in exposure of their hydrophobic cores to membranes. In line with these data, HCT116 cells with a genetic loss of 8 known $\mathrm{BH} 3-$ only proteins $\left(\mathrm{BAD}^{-/-}, \mathrm{BID}^{-/-}\right.$, $\mathrm{BIK}^{-1-}, \mathrm{BIM}^{-1-}, \mathrm{BMF}^{-1-}, \mathrm{HRK}^{-1-}, \mathrm{NOXA}^{-1-}$ and $\mathrm{PUMA}^{-1-}$ ) underwent apoptosis in a BAX/BAK-dependent manner once anti-apoptotic BCL-2 proteins were genetically or pharmacologically inactivated. ${ }^{61}$ Further, exogenous expression of either $\mathrm{BAX}$ or BAK in cells lacking the majority of BCL-2 family proteins (the above HCT116 cells lacking $8 \mathrm{BH} 3-$ only proteins with additional genetic loss of BCL-2, BCL-XL, MCL-, BCL-W, BFL/A1, BNIP3, NIX, BAX and BAK) resulted in spontaneous targeting of $B A X$ and $B A K$ to mitochondria and subsequent apoptosis, suggesting that BAX and BAK do not necessarily require $\mathrm{BH} 3-$ only proteins for activation in vitro. ${ }^{61}$ However, it must be kept in mind that cultured cells are abnormal, under stress owing to high oxygen levels, often transformed and are usually growing on plastic potentially altering the cytoplasmic environment, cell metabolism or lipid composition of the mitochondria resulting in conditions that spontaneously activate BAX and BAK.

Dance moves of the pore-formers - activated BAX/BAK undergo multiple conformation changes within the bilayer. BAX and BAK are comprised of nine alpha-helices and in their inactive forms adopt a globular structure. ${ }^{11,62}$ Inactive monomers of BAX and BAK are slightly different; the carboxyl-terminal transmembrane helix, $a 9$, is constitutively inserted into the MOM for BAK, whereas for BAX $a 9$ is sequestered to the protein core within the hydrophobic $\mathrm{BH} 3$ domain-binding groove resulting in a cytoplasmic localization. ${ }^{63,64}$ Activator $\mathrm{BH} 3$-only proteins bind to the $\mathrm{BH} 3$ domain-binding groove, displacing $a 9$, which then inserts into the bilayer resulting in BAX adopting a similar conformation to that of inactive BAK ${ }^{64-66}$ BAX/BAK disengages the amino $(a 1)$ and carboxyl-terminal ( $a 6-a 8)$ regions from the hydrophobic core of the protein that is formed by the $\mathrm{BH} 3$ domain-binding groove $(a 2-a 5) .{ }^{12,67-69}$ Then BAX/BAK embed into the bilayer with $a 5$ and $a 6$ helices partially inserted and $a 9$, adopting a transmembrane configuration (Figure 4; step 2). ${ }^{49,67,70-72}$ Determining whether there is a precise order of these changes and the equilibria between each step is important since a physiologically relevant intermediate conformation of BAX or BAK could be targeted pharmaceutically to modulate the regulation of MOMP. But so far, a defined temporal intermediate between inactive monomeric and membrane inserted dimeric BAX/BAK has not been found in physiologically relevant experimental conditions.

Dancing with a twin - activated monomers of BAX/BAK form symmetric homodimers. Of the $B C L-2$ family proteins $\mathrm{BAX} / \mathrm{BAK}$ are unique in that they first form heterodimers with activator $\mathrm{BH} 3-o n l y$ proteins and then transition by an unclear mechanism to homodimers with other active BAX/BAK monomers (Figure 4; step 3). ${ }^{73,74}$ The conundrum arises 


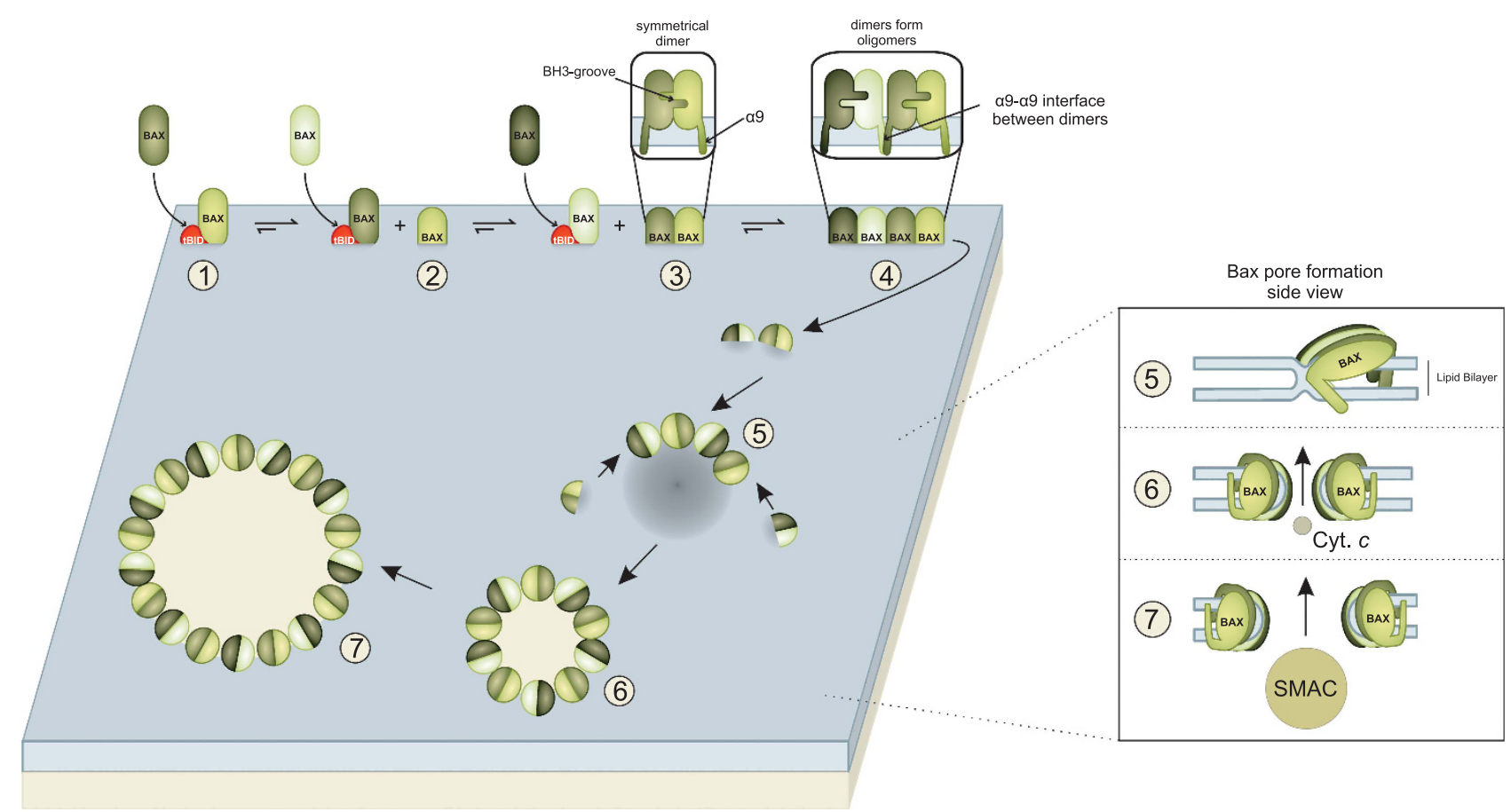

Figure 4 BAX activation is a multi-step process characterized by hetero-and homotypic interactions that result in MOMP. Full-length activator BH3-only proteins, like tBID, have a high affinity for membranes and bind them rapidly before interacting with the pore-formers, BAX and BAK. The following steps are shown for BAX activation; however, the BAK activation mechanism appears to be very similar. (Step 1) BAX interacts with tBID at the membrane. (Step 2) BAX then undergoes multiple conformation changes, inserting into the bilayer with $\alpha 9$ spanning the membrane. Insertion into the bilayer is the rate-limiting step in the BAX activation mechanism. (Step 3) The transition from the BAX and BH3only protein heterodimer to BAX homodimers is not well understood but would occur spontaneously if the homotypic interaction is of higher affinity than that of the heterotypic interaction between $\mathrm{BAX}$ and activator $\mathrm{BH} 3-0$ ly proteins. The end result is that the membrane-embedded active BAX monomers dimerize via reciprocal interactions between their BH3-grooves. (Step 4) BAX dimers interact with each other via multiple lower affinity interactions of which parallel $\alpha 9-\alpha 9$ interactions between dimers appear particularly important for the stabilization of large pores. (Step 5) BAX oligomers composed of symmetrical dimer subunits start to destabilize and thin the bilayer. Weak affinity interactions between dimers allow additional dimer subunits to add to the oligomer at any point. (Step 6) BAX oligomers form small pores in the bilayer that can initially release smaller intermembrane space (IMS) proteins like cytochrome $c(12 \mathrm{kDa})$. (Step 7) Continuing activation of BAX results in a higher concentration of dimers in the bilayer that add to the oligomer, resulting in pore expansion and the release of larger IMS proteins like SMAC (54 kDa dimer)

because the $\mathrm{BH} 3$ domain of the activator $\mathrm{BH}$-only protein binds inactive $\mathrm{BAX} / \mathrm{BAK}$ in the $\mathrm{BH} 3$ domain-binding groove and BAX/BAK dimerization involves symmetric binding between these $\mathrm{BH} 3$ domain-binding grooves, which also contain the $\mathrm{BH} 3$ domain, of each activated monomer. ${ }^{12,67,71,72,75}$ With similar interaction sites, activator BH3-only proteins would be expected to inhibit rather than activate BAX/BAK dimerization, which has not been observed for BAX/BAK even in the presence of excess activator. $^{36,76}$ In support of this, BID SAHBs, previously shown to activate BAK, inhibited BAK oligomerization when disulfide cross-linked to the $\mathrm{BAK} \mathrm{BH} 3$ domain-binding groove. ${ }^{11}$ This suggests that activator $\mathrm{BH} 3-$ only proteins leave the $\mathrm{BH} 3$ domain-binding groove in order for BAX/BAK oligomerization to proceed. However, at steady state $\mathrm{BH} 3$ activators can stay bound to BAX even after pore formation. ${ }^{20,50,77}$ These studies measured the entire population of BAX and BID via FRET (Förster resonance energy transfer) thus, it remains possible that there are subpopulations, one of $C B I D$ and BAX heterodimers and one of BAX oligomers. It is also possible that binding partners exchange rapidly at equilibrium despite their high affinities.

An attractive, hypothesis for what could be occurring is that at the bilayer, activator $\mathrm{BH} 3$-only proteins convert BAX/BAK from inactive monomers into active membrane-embedded monomers. ${ }^{73}$ This structural rearrangement could reduce the affinity between activator BH3-only proteins and active BAX/ BAK monomers such that BAX/BAK homodimerization displaces the activator $\mathrm{BH} 3$-only protein (Figure 4; step 2). Displacement is favored by inactive monomers being higher in concentration and having a higher affinity for the activator BH3-only proteins compared with the active monomers. This would explain why BH3-only proteins function as catalysts for BAX activation in certain experimental conditions. ${ }^{78}$ The displaced monomer is limited to two-dimensional diffusion within the bilayer, resulting in a high local concentration of active monomers. This results in the recruitment of multiple activated BAX/BAK monomers in close proximity and thereby assists dimer formation via high-affinity $\mathrm{BH} 3$ domain-binding groove interactions (Figure 4; step 3). The high-affinity $\mathrm{BH} 3$ domain-binding groove interactions in a dimer along with insertion into the bilayer drive BAX/BAK activation irreversibly towards dimers. Release of the $\mathrm{BH} 3$ protein would repeat this process resulting in a high local concentration of BAX/BAK dimers in the bilayer that further oligomerize thereby permeabilizing the membrane (Figure 4; step 4).

Dancing in a circle - low-affinity interactions allow for a dynamic BAX/BAK pore. Fluorescence-based kinetic studies revealed $\mathrm{BAX}$ insertion into the bilayers was rate-limiting 
and followed rapidly by BAX oligomerization. ${ }^{20}$ The last step to be characterized is determining exactly how BAX/BAK dimers dance as oligomers that permeabilize the MOM. Recently, single-molecule imaging of BAX showed BAX monomers form dimers in the bilayer that self-assemble into higher-order oligomers. ${ }^{73}$ This is consistent with biochemical data where BAX/BAK symmetrical homodimers can be disulfide crosslinked into higher-order oligomers ${ }^{71,74}$ and with structural data of active BAX/BAK at membranes. ${ }^{67,72}$ In addition, the BAX/ BAK inhibitors MSN-125, MSN-50 and DAN004 prevent BAX oligomerization but not symmetrical dimer formation. ${ }^{79}$ These inhibitors prevented some but not all of the interfaces within symmetrical dimers suggesting that proper dimer formation is prerequisite for oligomerization and pore formation.

Chemical cross-linking studies report inter-dimer crosslinks at a number of positions between one BAX molecule in a dimer $\left(a \#^{1}\right)$ and another in a separate dimer $\left(a \#^{2}\right)$ such as $a 6^{1}$ : $a 6^{2}, a 1^{1}: a 1^{2}, a 3^{1}: a 5^{2}$ and $a 9^{1}: a 9^{2} .{ }^{71,72,80}$ The interface formed between $a 9$ helices within the bilayer is particularly important for stabilizing large pores. Deletion of $a 9$ or mutations to $a 9$ that disrupt the inter-dimer interface results in the release of smaller IMS proteins like cytochrome $c(12 \mathrm{kDa})$ but not larger proteins like SMAC (54 kDa dimer in cells). ${ }^{71,81}$ Consistent with observations that BAX/BAK form dynamic pores that enlarge over time with variable sizes dependent on BAX/BAK concentration, ${ }^{82,83}$ direct visualization of $B A X$ in cells revealed that homo-oligomers form lines, arcs and rings of various sizes on mitochondria. ${ }^{84}$ In this study $97 \%$ of BAX rings formed pores in isolated lipid bilayers versus $12 \%$ of BAX arcs. This supports observations that BAX lines the edges of both small and large pores with similar protein density. ${ }^{85}$ Together, these data suggest a model whereby oligomers are formed by dimers linked together by many weak affinity interactions (Figure 4; step 4). This model is attractive because weak affinity interactions between dimers explain how pores enlarge over time: newly formed dimers join together end-to-end as lines and arcs that eventually close to form pores that are expanded by additional dimer subunits (Figure 4; step 5-7).

\section{Changing Dance Partners Within the Cell}

PTMs alter the abundance and affinities of BCL-2 family proteins in cells. Just as different songs affect dancing styles, post-translational modifications (PTMs) of BCL-2 family proteins have a role in regulating their interactions. PTMs can affect stability, localization and function of BCL-2 family proteins and can promote or inhibit apoptosis. PTMs regulating $\mathrm{BCL}-2$ family proteins were reviewed comprehensively. ${ }^{86}$ However, the majority of PTMs are single reports that have not been independently confirmed. In other cases, two or more reports conclude opposite functional effects. For example, phosphorylation of BCL-2 at S70 was reported to increase ${ }^{87-89}$ or inhibit apoptosis. ${ }^{90-92}$

To illustrate the range of activities ascribed to posttranslational modifications we generated an updated list of PTMs reported for just BAX (Table 2). Even for the well-studied protein BAX there are only two independently confirmed PTMs, polyubiquitination and phosphorylation of $\mathrm{S} 184$ of BAX. Polyubiquitination targets BAX for proteasomal degradation. Proteasomal degradation of monomeric BAX would

Table 2 Post-translational modifications of BAX

\begin{tabular}{|c|c|c|c|c|}
\hline Modification and residue & Modified by & Functional consequence & Year & PMID \\
\hline \multirow[t]{2}{*}{ Phosphorylation S184 (H9) } & AKT & Inactivates BAX, prevents translocation from cytosol to mitochondria & $\begin{array}{l}2004 \\
2005 \\
2009 \\
2016 \\
2016\end{array}$ & $\begin{array}{l}14766748 \\
15642728 \\
19376889 \\
26763134 \\
28357332\end{array}$ \\
\hline & PKC-zeta & Inactivates and destabilizes BAX & 2007 & 17525161 \\
\hline Phosphorylation S163 (H8-H9 loop) & GSK-3P & Activates BAX by increased targeting to mitochondria & 2004 & 15525785 \\
\hline Phosphorylation T167 (H8-H9 loop) & JNK and p38 & Phosphorylation inactivates BAX Inhibits apoptosis & 2006 & 16709574 \\
\hline Phosphorylation T135 or T140 (H6) & Unknown & $\begin{array}{l}\text { Unknown. Observed in a pre-malignant (AT1), but not a malignant cell } \\
\text { line (CA1a) }\end{array}$ & 2009 & 19194518 \\
\hline Phosphorylation T22(H1) & Unknown & HTS, needs validation & 2011 & 21712546 \\
\hline Phosphorylation T85 (H3-H4 loop) & Unknown & & 2015 & 25814448 \\
\hline Dephosphorylation T172, T174, T186 & WIP1 & Downregulates BAX. Inhibits apoptosis & 2013 & 23907458 \\
\hline Dephosphorylation & PP2A & Promotes apoptosis & 2006 & 16679323 \\
\hline Cleavage G28/G29 (H1) & Calpain & $\begin{array}{l}\text { Releases C-terminal BAX lacking amino acids } 129 \text { of the N-terminus, } \\
\text { increases its apoptotic activity by unknown mechanism Promotes } \\
\text { apoptosis }\end{array}$ & 2003 & 12490315 \\
\hline \multirow{2}{*}{$\begin{array}{l}\text { PolyUbiquitination non-specific site } \\
\text { (9 lysines in BAX) }\end{array}$} & unknown & Inhibits apoptosis targets BAX for proteasomal degradation & 1998 & 9438391 \\
\hline & $\begin{array}{l}\text { PARKIN } \\
\text { IBRDC2 }\end{array}$ & & $\begin{array}{l}2000 \\
2012 \\
2010\end{array}$ & $\begin{array}{l}10725400 \\
22460798 \\
20300062\end{array}$ \\
\hline
\end{tabular}

Reported post-translational modifications (PTMs) of BAX. Helix in BAX where modification takes place is indicated (H\#). Only phosphorylation of S184 and ubiquitination of BAX have been independently confirmed by multiple labs (shaded). Where the same functional consequence is reported in multiple studies rows were merged for clarity. The functional consequence of S184 phosphorylation is controversial as it has been reported that it either activates or inhibits BAX. The corresponding publication year and Pubmed ID (PMID) are listed for each study 
decrease BAX concentration and shift activator $\mathrm{BH} 3$ binding to anti-apoptotic proteins (Figure 3a).

Phosphorylation could alter the core mechanism of 'dance' steps detailed above by introducing a large negatively charged phosphate to regions critical for BAX function. Phosphorylation of residue $\mathrm{S} 184$ by $\mathrm{AKT}$ is known to inhibit BAX. ${ }^{93,94}$ Currently, the precise mechanism of how S184 phosphorylation affects BAX activation remains to be elucidated. However, to understand $\mathrm{BCL}-2$ family protein regulation in vivo it will be imperative to understand how PTMs change BCL-2 familybinding affinities for proteins and membranes, and their subcellular localizations both of which can alter the fate of the cell.

Alternate dance venues in cells - changing localizations of the BCL-2 family. The BCL-2 family proteins have diverse localizations within cells, likely dictated by their different affinities for various intracellular membranes and

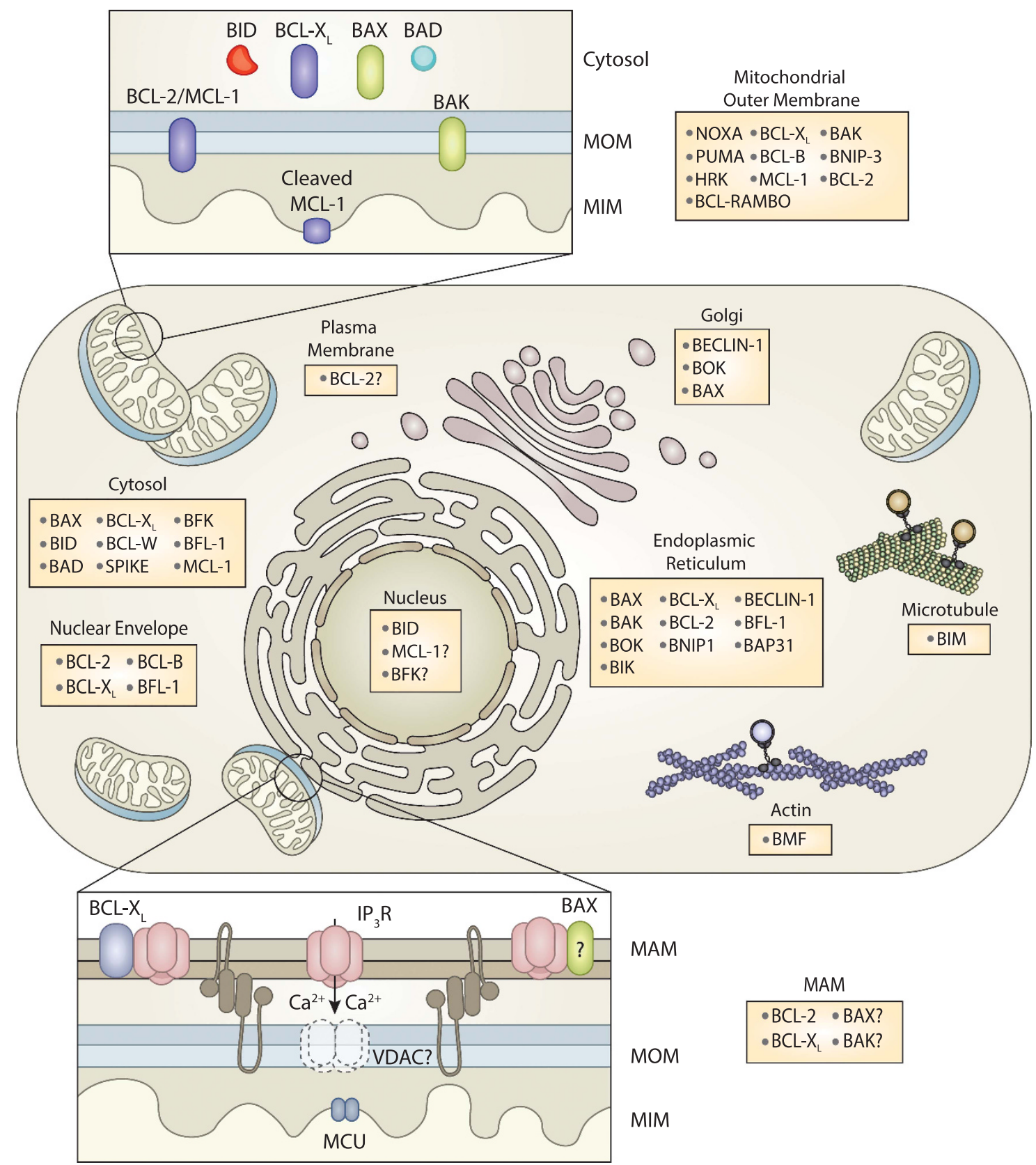

Figure 5 BCL-2 family protein subcellular localization in non-apoptotic cells BCL-2 family proteins reported at each location are listed in the corresponding box. Uncertainty or data for which there are conflicting reports are indicated by a '?'. Localization that changes during apoptosis is summarized in Tables $3 \mathrm{~A}$ and $3 \mathrm{~B}$. Interactions at the mitochondria are shown in the enlargement top left. Interactions at the mitochondrial associated membrane (MAM), a subdomain of the endoplasmic reticulum in close contact with mitochondria are enlarged below left. Among other proteins, mitofusin proteins (shown as dimer linking the two membranes) bring a specialized subdomain of ER membranes in contact with the mitochondrial outer membrane forming the MAM 
Table 3A Localization of BCL-2 Family proteins

\begin{tabular}{|c|c|c|c|c|c|c|c|c|c|c|}
\hline & \multicolumn{10}{|c|}{ Localization } \\
\hline Protein & ER & NE & TGN & Cytosol & MOM & MM & MIM & \begin{tabular}{|c|}
$\begin{array}{c}\text { Cyto- } \\
\text { skeleton }\end{array}$ \\
\end{tabular} & $\begin{array}{c}\text { Plasma } \\
\text { membrane }\end{array}$ & Nucleus \\
\hline BCL-2 & $\overline{X X}$ & & & & $X X$ & & & & & \\
\hline BFL-1 & & & & & & & & & & \\
\hline \multirow{2}{*}{$B C L-X_{L}$} & & & & & & & & & & \\
\hline & & & & & $X X$ & & & & & \\
\hline BCL-W & & & & & & & & & & \\
\hline \multirow{2}{*}{ MCL-1 } & & & & & $X X$ & & & & & \\
\hline & & & & & $X X$ & & & & & \\
\hline BCL-G & & & & & $X X$ & & & & & \\
\hline \multirow{2}{*}{ BAX } & & & & $X X$ & & & & & & \\
\hline & & & & & $X X$ & & & & & \\
\hline BAK & & & & & $X X$ & & & & & \\
\hline $\mathrm{BOK}$ & $\mathrm{XX}$ & & & & & & & & & \\
\hline \multirow{2}{*}{ BMF } & & & & & & & & & & \\
\hline & & & & & & & & & & \\
\hline \multirow{2}{*}{ BIM } & & & & & & & & & & \\
\hline & & & & & & & & & & \\
\hline BID & & & & $x x$ & & & & & & \\
\hline PUMA & & & & & $x x$ & & & & & \\
\hline \multirow{2}{*}{ NOXA } & & & & & $X X$ & & & & & \\
\hline & & & & & $x X$ & & & & & \\
\hline \multirow{2}{*}{ HRK } & & & & & & & & & & \\
\hline & & & & & & & & & & \\
\hline \multirow{2}{*}{ BAD } & & & & $X X$ & & & & & & \\
\hline & $\mathrm{XX}$ & & & & & & & & & \\
\hline BECLIN-1 & $\overline{X X}$ & & & & & & & & & \\
\hline \multicolumn{11}{|l|}{ BNIP } \\
\hline SPIKE & & & & $\overline{X X}$ & & & & & & \\
\hline BAP31 & $X X$ & & & & & & & & & \\
\hline \multicolumn{11}{|l|}{ BCL-G } \\
\hline BFK & & & & $X X$ & & & & & & \\
\hline BCL-Rambo & & & & & $X X$ & & & & & \\
\hline
\end{tabular}

Abbreviations

$\begin{array}{cl}\text { ER } & \text { Endoplasmic Reticulum } \\ \text { NE } & \text { Nuclear Envelope } \\ \text { MOM } & \text { Mitochondrial Outer Membrane } \\ \text { MIM } & \text { Mitochondrial Inner Membrane } \\ \text { MM } & \text { Mitochondrial Matrix } \\ \text { TGN } & \text { trans Golgi network }\end{array}$

normal conditions

apoptotic conditions

XX predominant localization

Heat map of reported localizations for BCL-2 family proteins Proteins reported in multiple locations or that change location in growth and apoptotic conditions are shaded light and dark gray, respectively. XX indicates predominant localization for proteins reported at multiple locations 
Table 3B Detailed localization information and references

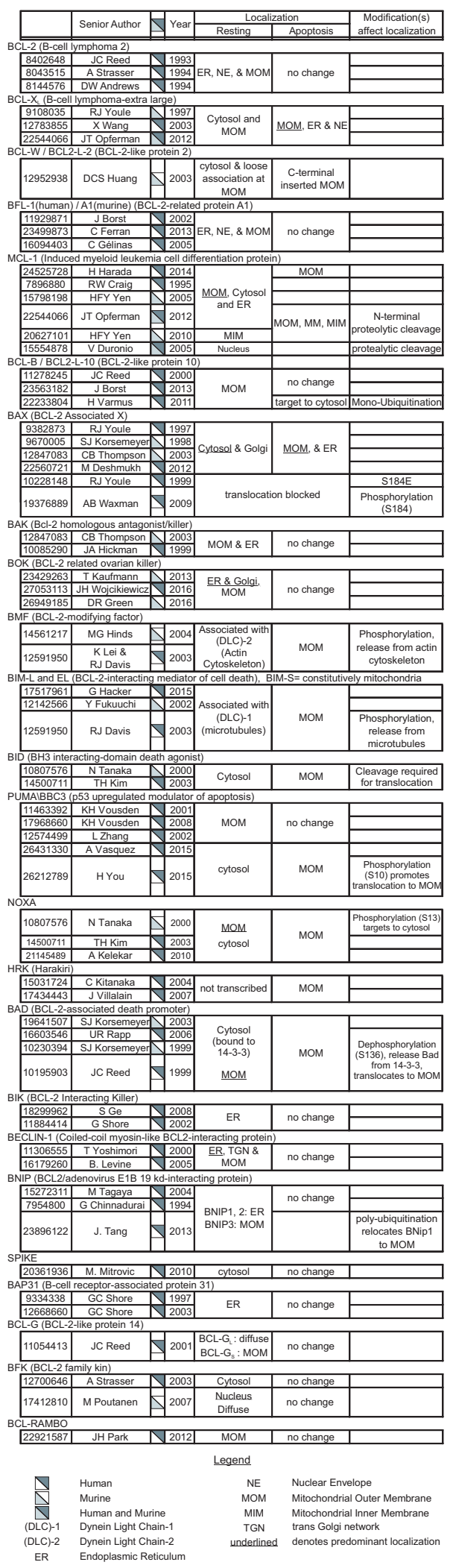

binding partners at each location (Figure 5, Tables $3 \mathrm{~A}$ and $3 B)$. The localization of BCL-2 family proteins results from complex binding equilibria with membranes and other proteins within the cell. Localization dictates the available binding partners and therefore BCL-2 family response to different cell death stimuli. The subcellular localization of BCL-2 family proteins may also be important for monitoring various cellular processes and/or may be requisite to alternate functions performed by the proteins in nonapoptotic cells.

For example, detachment from the matrix and some drug treatments result in perturbations of the cytoskeleton that in many cell types causes a specialized form of apoptosis called anoikis. In response to anoikis BIM and BMF have been reported to translocate from the cytoskeleton, their location in non-apoptotic cells, to the MOM (Tables $3 \mathrm{~A}$ and 3B,Figure 5). Moreover, loss of either protein results in protection from anoikis and resistance to cytoskeleton altering drugs like paclitaxel. ${ }^{95,96}$ It seems likely therefore, that localization of $\mathrm{BIM}$ and BMF at the cytoskeleton permits monitoring cellular fitness and initiation of an apoptotic signal in response to cytoskeletal perturbation.

The most widely recognized non-mitochondrial localization for BCL-2 family proteins is the endoplasmic reticulum (ER) where they regulate calcium homeostasis, ER stress, autophagy and apoptosis. ${ }^{97}$ The mechanism by which BCL-2 proteins regulate ER stress and calcium homeostasis and how this relates to apoptosis is not clear. ${ }^{98} \mathrm{BCL}-\mathrm{X}_{\mathrm{L}}, \mathrm{BCL}-2$, MCL-1, BAX and BAK have all been reported to regulate calcium release from the ER by interacting with inositol triphosphate receptors (IP3R), a ligand-gated calcium channel. ${ }^{98}$ There is accumulating evidence that this interaction is mediated by the $\mathrm{BH} 4$ domain of the multi-domain antiapoptotic proteins. ${ }^{99}$ Moreover, BCL-2 and BCL- $\mathrm{X}_{\mathrm{L}}$ can localize at the mitochondria-associated ER membranes, with Type III IP3Rs favouring transmission of calcium to the mitochondria, reducing calcium stores (Figure 5, panel B inset). ${ }^{100,101}$ Although many details remain unclear, it has been hypothesized that anti-apoptotic proteins promote the slow leak of calcium from the ER, decreasing the potential for strong signaling to mitochondria and thereby inhibiting apoptosis. ${ }^{101}$ BAX/BAK and BH3-only proteins may oppose calcium leakage by binding BCL-2/BCL- $X_{L}$ or IP3R, increasing calcium stores and promoting apoptosis. ${ }^{102,103}$ However, there are many areas of controversy and additional models for the role of BCL-2 family proteins in calcium signaling and ER stress. ${ }^{98}$ Nevertheless, the preponderance of evidence suggests that $\mathrm{BCL}-2$ family proteins function differently at the $\mathrm{ER}$ and mitochondria.

\section{Using Small Molecules with High Affinities to BCL-2 Family Proteins to Control the Dance of Death}

Developing small molecule modulators of BCL-2 family proteins has been a high priority for major pharmaceutical companies for more than a decade. Many cancer cells are 'addicted' to the expression of anti-apoptotic BCL-2 family proteins because in their absence the cells die faster than they grow. Such cells are described as 'primed for death' requiring only a 'push' in the right direction to trigger MOMP and 
subsequent apoptosis. ${ }^{104}$ Inactivating the anti-apoptotic BCL-2 family proteins with small molecule $\mathrm{BH} 3$ mimetic drugs is one potential 'push' as displacing the active but sequestered pro-apoptotic proteins results in MOMP. ${ }^{9,105,106}$ Small molecule BH3 mimetics, like ABT-263 (Navitoclax) and ABT-199 (Venetoclax), mimic the binding of $\mathrm{BH} 3$ peptides to the hydrophobic $\mathrm{BH} 3$ domain-binding groove of anti-apoptotic proteins and thus displace $\mathrm{BH} 3$-only proteins and active BAX/BAK from anti-apoptotic proteins. ${ }^{107,108}$ By binding to the $\mathrm{BH} 3$ domain-binding grooves of anti-apoptotic proteins, ABT-263 inhibits BCL-2, BCL-XL and BCL-W, whereas ABT-199 only inhibits BCL-2. ABT-199 is approved for use in chronic lymphocytic leukemia and both drugs are being used in dozens of clinical trials as single agents and in combination with other therapies. ${ }^{109}$

Some cancers depend primarily on MCL-1 for survival ${ }^{110-112}$ and others acquire resistance to drugs that target $\mathrm{BCL}-2 / \mathrm{BCL}-\mathrm{XL} / \mathrm{BCL}-\mathrm{W}$ by upregulating MCL-1. ${ }^{113}$ The small molecule MCL-1 inhibitor, $\mathrm{S} 63845$ shows promise as a therapeutic. $^{114}$ S63845 was efficacious in killing multiple cancer-derived cell lines in vitro and had potent anti-tumor activity in pre-clinical mouse models of hematological malignancies in vivo while sparing normal tissues. Another cancer treatment strategy would be small molecule activation of BAX and/or BAK. However, it has yet to be determined whether such small molecules have any therapeutic index in cancer. ${ }^{53}$

ABT-263 and ABT-199 were optimized to displace BAD BH3 peptides from $\mathrm{C}$-terminally truncated anti-apoptotic proteins in solution. However, the significant differences in BCL-2 family interactions between full-length proteins at membranes compared with truncated proteins in solution described above extend to interactions with drugs. For example, even though ABT-263 and the functionally similar BH3 mimetic ABT-737 displace BID and BAD, unlike what was seen in vitro using peptides and truncated proteins, in live cells the compounds do not displace BIM from BCL-2 or BCL-X $\mathrm{L}^{115,116}$ Recently, this result was independently confirmed for BIM with the BCL-2 inhibitor ABT-199 and BCL-X inhibitor WEHI-539 and extended to include resistance in live cells of PUMA interactions with full-length $B C L-2$ and $B C L-X_{L}$, but not C-terminally truncated cytoplasmic anti-apoptotic proteins. ${ }^{117}$ These studies are consistent with the tenets of the embedded together model in which membrane binding alters the functional interactions of BCL-2 family proteins via conformation changes that alter binding affinities. It has not been determined whether membrane binding, additional interactions outside of the $\mathrm{BH} 3$ domains or both contribute to the apparent enhanced affinity between these BCL-2 family proteins at membranes. However, these studies highlight the need to examine BCL-2 family interactions, and their pharmacological manipulation, in live cells.

\section{Modeling the dance of death}

Pharmacological manipulation of the BCL-2 family activities will be limited until there is a more quantitative understanding of how BCL-2 family proteins regulate apoptosis in cells. Quantitative modeling in combination with experimental data can be used to explain, predict and understand the behavior of complex biological processes while validating and discriminating competing models. Quantitative modeling was successfully used to explain the substantial cell-to-cell variability in cell death kinetics upon induction of extrinsic apoptosis. ${ }^{5}$ A similar approach using Bayesian statistics discriminated between the competing models of BCL-2 family interactions by incorporating previously published binding affinities between BCL-2 family proteins. ${ }^{118}$ This study concluded that only the 'embedded together' model reproduces MOMP dynamics observed in single-cells. These quantitative models provided important insights into the complex regulation of the BCL-2 family proteins that likely would have been missed otherwise. The large number of BCL-2 family proteins and differences in their binding affinities and mechanisms of action make predicting the apoptotic response of cells very difficult. We expect additional fine tuning of quantitative models will require inclusion of all (or most) of the determinants discussed in this review such as the range of concentrations of BCL-2 family proteins and their various affinities and binding partners in cells. As dysregulation of BCL-2 family proteins has wide-ranging implications in human disease, as difficult as it will be, quantitatively modeling the 'dance of death' by the $\mathrm{Bcl}-2$ family proteins will be required to understand how apoptosis can be modulated to most effectively treat human disease.

\section{Conflict of Interest}

The authors declare no conflict of interest.

Acknowledgements. We thank Lesia Szyca for help with creation of all of the illustrations. This work was supported by Canadian Institutes of Health Research foundation grant FDN143312 (DWA).

1. Tait SW, Green DR. Mitochondria and cell death: outer membrane permeabilization and beyond. Nat Rev Mol Cell Biol 2010; 11: 621-632.

2. Mcllwain DR, Berger T, Mak TW. Caspase functions in cell death and disease. Cold Spring Harb Perspect Biol 2015; 7 : 4.

3. Goldstein JC, Waterhouse NJ, Juin P, Evan GI, Green DR. The coordinate release of cytochrome $\mathrm{C}$ during apoptosis is rapid, complete and kinetically invariant. Nat Cell Biol 2000; 2: 156-162.

4. Rehm M, Dussmann H, Janicke RU, Tavare JM, Kogel D, Prehn JH. Single-cell fluorescence resonance energy transfer analysis demonstrates that caspase activation during apoptosis is a rapid process. Role of caspase-3. J Biol Chem 2002; 277: 24506-24514

5. Albeck JG, Burke JM, Spencer SL, Lauffenburger DA, Sorger PK. Modeling a snap-action, variable-delay switch controlling extrinsic cell death. PLOS Biol 2008; 6: 2831-2852.

6. Lomonosova $\mathrm{E}$, Chinnadurai $\mathrm{G}$. BH3-only proteins in apoptosis and beyond: an overview. Oncogene 2008; 27: S2-19.

7. Shamas-Din A, Brahmbhatt $H$, Leber B, Andrews DW. BH3-only proteins: orchestrators of apoptosis. Biochim Biophys Acta 2011; 1813: 508-520.

8. Billen LP, Shamas-Din A, Andrews DW. Bid: a Bax-like BH3 proteinOncogene 2009; 27: S93-104.

9. Shamas-Din A, Kale J, Leber B, Andrews DW. Mechanisms of action of Bcl-2 family proteins. Cold Spring Harb Perspect Biol 2013; 5: a008714.

10. Leber B, Lin J, Andrews DW. Embedded together: the life and death consequences of interaction of the Bcl-2 family with membranes. Apoptosis 2007; 12: 897-911.

11. Moldoveanu T, Grace CR, Llambi F, Nourse A, Fitzgerald P, Gehring K et al. BID-induced structural changes in BAK promote apoptosis. Nat Struct Mol Biol 2013; 20: 589-597.

12. Czabotar PE, Westphal D, Dewson G, Ma S, Hockings C, Fairlie WD et al. Bax crystal structures reveal how $\mathrm{BH} 3$ domains activate $\mathrm{Bax}$ and nucleate its oligomerization to induce apoptosis. Cell 2013; 152: 519-531.

13. Liu Q, Moldoveanu T, Sprules T, Matta-Camacho E, Mansur-Azzam N, Gehring K. Apoptotic regulation by MCL-1 through heterodimerization. J Biol Chem 2010; 285 : 19615-19624.

14. Ku B, Liang $\mathrm{C}$, Jung JU, Oh BH. Evidence that inhibition of BAX activation by BCL-2 involves its tight and preferential interaction with the BH3 domain of BAX. Cell Res 2011; 21: $627-641$. 
15. Petros AM, Nettesheim DG, Wang Y, Olejniczak ET, Meadows RP, Mack J et al. Rationale for Bcl-xL/Bad peptide complex formation from structure, mutagenesis, and biophysical studies. Protein Sci 2000; 9: 2528-2534.

16. Chi X, Kale J, Leber B, Andrews DW. Regulating cell death at, on, and in membranes. Biochim Biophys Acta 2014; 1843: 2100-2113.

17. Shamas-Din A, Bindner S, Zhu W, Zaltsman Y, Campbell C, Gross A et al. tBid undergoes multiple conformational changes at the membrane required for Bax activation. J Biol Chem 2013; 288: 22111-22127.

18. Korsmeyer SJ, Shutter JR, Veis DJ, Merry DE, Oltvai ZN. Bcl-2/Bax: a rheostat that regulates an anti-oxidant pathway and cell death. Semin Cancer Biol 1993; 4: 327-332.

19. Billen LP, Kokoski CL, Lovell JF, Leber B, Andrews DW. Bcl-XL inhibits membrane permeabilization by competing with Bax. PLoS Biol 2008; 6: e147.

20. Lovell JF, Billen LP, Bindner S, Shamas-Din A, Fradin C, Leber B et al. Membrane binding by tBid initiates an ordered series of events culminating in membrane permeabilization by Bax. Cell 2008; 135: 1074-1084.

21. Wang ZX. An exact mathematical expression for describing competitive binding of two different ligands to a protein molecule. FEBS Lett 1995; 360: 111-114.

22. Sattler M, Liang H, Nettesheim D, Meadows RP, Harlan JE, Eberstadt M et al. Structure of Bcl-xL-Bak peptide complex: recognition between regulators of apoptosis. Science 1997; 275: 983-986.

23. Kelekar A, Chang BS, Harlan JE, Fesik SW, Thompson CB. Bad is a BH3 domain-containing protein that forms an inactivating dimer with Bcl-XL. Mol Cell Biol 1997; 17: 7040-7046.

24. Chen L, Willis SN, Wei A, Smith BJ, Fletcher JI, Hinds MG et al. Differential targeting of prosurvival $\mathrm{Bcl}-2$ proteins by their $\mathrm{BH} 3-$ only ligands allows complementary apoptotic function. Mol Cell 2005; 17: 393-403.

25. Petros AM, Medek A, Nettesheim DG, Kim DH, Yoon HS, Swift K et al. Solution structure of the antiapoptotic protein bcl-2. Proc Natl Acad Sci USA 2001; 98: 3012-3017.

26. Czabotar PE, Lee EF, Thompson GV, Wardak AZ, Fairlie WD, Colman PM. Mutation to Bax beyond the $\mathrm{BH} 3$ domain disrupts interactions with pro-survival proteins and promotes apoptosis. J Biol Chem 2011; 286: 7123-7131.

27. Polster BM, Basanez G, Young M, Suzuki M, Fiskum G. Inhibition of Bax-induced cytochrome c release from neural cell and brain mitochondria by dibucaine and propranolol. $J$ Neuroscience 2003; 23: 2735-2743.

28. Eskes R, Antonsson B, Osen-Sand A, Montessuit S, Richter C, Sadoul R et al. Bax-induced cytochrome $C$ release from mitochondria is independent of the permeability transition pore but highly dependent on Mg2+ ions. J Cell Biol 1998; 143: 217-224.

29. Dutta S, Gulla S, Chen TS, Fire E, Grant RA, Keating AE. Determinants of BH3 binding specificity for Mcl-1 versus Bcl-xL. J Mol Biol 2010; 398: 747-762.

30. Cheng C, Liu Y, Balasis ME, Garner TP, Li J, Simmons NL et al. Marinopyrrole derivatives with sulfide spacers as selective disruptors of Mcl-1 binding to pro-apoptotic protein Bim. Marine Drugs 2014; 12: 4311-4325.

31. Smith AJ, Dai H, Correia C, Takahashi R, Lee SH, Schmitz I et al. Noxa/Bcl-2 protein interactions contribute to bortezomib resistance in human lymphoid cells. $\mathrm{J}$ Biol Chem 2011; 286: 17682-17692.

32. Hockings C, Anwari K, Ninnis RL, Brouwer J, O'Hely M, Evangelista M et al. Bid chimeras indicate that most $\mathrm{BH}$-only proteins can directly activate Bak and Bax, and show no preference for Bak versus Bax. Cell Death Dis 2015; 6: e1735.

33. Merino D, Giam M, Hughes PD, Siggs OM, Heger K, O'Reilly LA et al. The role of BH3-only protein Bim extends beyond inhibiting Bcl-2-like prosurvival proteins. J Cell Biol 2009; 186: 355-362.

34. Willis SN, Fletcher JI, Kaufmann T, van Delft MF, Chen L, Czabotar PE et al. Apoptosis initiated when BH3 ligands engage multiple Bcl-2 homologs, not Bax or Bak. Science 2007; 315: 856-859.

35. Du H, Wolf J, Schafer B, Moldoveanu T, Chipuk JE, Kuwana T. BH3 domains other than Bim and Bid can directly activate Bax/Bak. J Biol Chem 2011; 286: 491-501.

36. Kuwana T, Bouchier-Hayes L, Chipuk JE, Bonzon C, Sullivan BA, Green DR et al. BH3 domains of BH3-only proteins differentially regulate Bax-mediated mitochondrial membrane permeabilization both directly and indirectly. Mol Cell 2005; 17: 525-535.

37. Sarosiek KA, Chi X, Bachman JA, Sims JJ, Montero J, Patel L et al. BID preferentially activates BAK while BIM preferentially activates BAX, affecting chemotherapy response. Mol Cell 2013; 51: 751-765.

38. Walensky LD, Kung AL, Escher I, Malia TJ, Barbuto S, Wright RD et al. Activation of apoptosis in vivo by a hydrocarbon-stapled BH3 helix. Science 2004; 305: 1466-1470.

39. Gavathiotis E, Suzuki M, Davis ML, Pitter K, Bird GH, Katz SG et al. BAX activation is initiated at a novel interaction site. Nature 2008; 455: 1076-1081.

40. Walensky LD, Pitter K, Morash J, Oh KJ, Barbuto S, Fisher J et al. A stapled BID BH3 helix directly binds and activates BAX. Mol Cell 2006; 24: 199-210.

41. Wilfling F, Weber A, Potthoff S, Vogtle FN, Meisinger C, Paschen SA et al. BH3-only proteins are tail-anchored in the outer mitochondrial membrane and can initiate the activation of Bax. Cell Death Differ 2012; 19: 1328-1336.

42. Lutter M, Fang M, Luo X, Nishijima M, Xie X, Wang X. Cardiolipin provides specificity for targeting of tBid to mitochondria. Nat Cell Biol 2000; 2: 754-761.

43. Kim TH, Zhao Y, Ding WX, Shin JN, He X, Seo YW et al. Bid-cardiolipin interaction at mitochondrial contact site contributes to mitochondrial cristae reorganization and cytochrome C release. Mol Biol Cell 2004; 15: 3061-3072.

44. Oh KJ, Barbuto S, Pitter K, Morash J, Walensky LD, Korsmeyer SJ. A membrane-targeted BID BCL-2 homology 3 peptide is sufficient for high potency activation of BAX in vitro. J Biol Chem 2006; 281: 36999-37008.
45. Birkinshaw RW, Czabotar PE. The BCL-2 family of proteins and mitochondrial outer membrane permeabilisation. Semin Cell Dev Biol 2017 (in press).

46. Llambi F, Moldoveanu T, Tait SW, Bouchier-Hayes L, Temirov J, McCormick LL et al. A unified model of mammalian BCL-2 protein family interactions at the mitochondria. Mol Cell 2011; 44: 517-531.

47. Cosentino K, Garcia-Saez AJ. Bax and Bak pores: are we closing the circle? Trends Cell Biol 2017; 27: 266-275.

48. Garner TP, Reyna DE, Priyadarshi A, Chen HC, Li S, Wu Y et al. An autoinhibited dimeric form of BAX regulates the BAX activation pathway. Mol Cell 2016; 64: 431.

49. Westphal D, Dewson G, Menard M, Frederick P, lyer S, Bartolo R et al. Apoptotic pore formation is associated with in-plane insertion of Bak or Bax central helices into the mitochondrial outer membrane. Proc Natl Acad Sci USA 2014; 111: E4076-E4085.

50. Shamas-Din A, Bindner S, Chi X, Leber B, Andrews DW, Fradin C. Distinct lipid effects on tBid and Bim activation of membrane permeabilization by pro-apoptotic Bax. Biochem $J$ 2015; 467: 495-505.

51. Weber A, Paschen SA, Heger K, Wiffling F, Frankenberg T, Bauerschmitt $\mathrm{H}$ et al. BimSinduced apoptosis requires mitochondrial localization but not interaction with anti-apoptotic Bcl-2 proteins. J Cell Biol 2007; 177: 625-636.

52. Iyer $\mathrm{S}$, Anwari $\mathrm{K}$, Alsop AE, Yuen WS, Huang DC, Carroll $\mathrm{J}$ et al. Identification of an activation site in Bak and mitochondrial Bax triggered by antibodies. Nat Commun 2016; 7 11734

53. Brahmbhatt $\mathrm{H}$, Uehling D, Al-Awar R, Leber B, Andrews D. Small molecules reveal an alternative mechanism of Bax activation. Biochem J 2016; 473: 1073-1083.

54. Pritz JR, Wachter F, Lee S, Luccarelli J, Wales TE, Cohen DT et al. Allosteric sensitization of proapoptotic BAX. Nat Chem Biol 2017; 13: 961-967.

55. Pagliari LJ, Kuwana T, Bonzon C, Newmeyer DD, Tu S, Beere HM et al. The multidomain proapoptotic molecules Bax and Bak are directly activated by heat. Proc Natl Acad Sci USA 2005; 102: 17975-17980

56. Cartron PF, Oliver L, Mayat E, Meflah K, Vallette FM. Impact of $\mathrm{pH}$ on Bax alpha conformation, oligomerisation and mitochondrial integration. FEBS Lett 2004; 578: 41-46.

57. Hsu YT, Youle RJ. Nonionic detergents induce dimerization among members of the Bcl2 family. J Biol Chem 1997; 272: 13829-13834.

58. Kuwana T, Mackey MR, Perkins G, Ellisman MH, Latterich M, Schneiter R et al. Bid, Bax, and lipids cooperate to form supramolecular openings in the outer mitochondria membrane. Cell 2002; 111: 331-342.

59. Yethon JA, Epand RF, Leber B, Epand RM, Andrews DW. Interaction with a membrane surface triggers a reversible conformational change in Bax normally associated with induction of apoptosis. J Biol Chem 2003; 278: 48935-48941.

60. Chipuk JE, McStay GP, Bharti A, Kuwana T, Clarke CJ, Siskind LJ et al. Sphingolipid metabolism cooperates with BAK and BAX to promote the mitochondrial pathway of apoptosis. Cell 2012; 148: 988-1000.

61. O'Neill KL, Huang K, Zhang J, Chen Y, Luo X. Inactivation of prosurvival Bcl-2 proteins activates Bax/Bak through the outer mitochondrial membrane. Genes Dev 2016; 30 973-988.

62. Suzuki M, Youle RJ, Tjandra N. Structure of Bax: coregulation of dimer formation and intracellular localization. Cell 2000; 103: 645-654.

63. Setoguchi K, Otera H, Mihara K. Cytosolic factor- and TOM-independent import of C-tailanchored mitochondrial outer membrane proteins. EMBO J 2006; 25: 5635-5647.

64. Nechushtan A, Smith CL, Hsu YT, Youle RJ. Conformation of the Bax C-terminus regulates subcellular location and cell death. EMBO J 1999; 18: 2330-2341.

65. Robin AY, Krishna Kumar K, Westphal D, Wardak AZ, Thompson GV, Dewson G et al. Crystal structure of Bax bound to the $\mathrm{BH} 3$ peptide of Bim identifies important contacts for interaction. Cell Death Dis 2015; 6: e1809.

66. Dai H, Smith A, Meng XW, Schneider PA, Pang YP, Kaufmann SH. Transient binding of an activator $\mathrm{BH} 3$ domain to the Bak $\mathrm{BH} 3$-binding groove initiates Bak oligomerization. $\mathrm{J}$ Cell Biol 2011; 194: 39-48.

67. Bleicken S, Jeschke G, Stegmueller C, Salvador-Gallego R, Garcia-Saez AJ, Bordignon E. Structural model of active Bax at the membrane. Mol Cell 2014; 56: 496-505.

68. Brouwer JM, Westphal D, Dewson G, Robin AY, Uren RT, Bartolo R et al. Bak core and latch domains separate during activation, and freed core domains form symmetric homodimers. Mol Cell 2014; 55: 938-946.

69. Kim H, Tu HC, Ren D, Takeuchi O, Jeffers JR, Zambetti GP et al. Stepwise activation of $\mathrm{BAX}$ and BAK by tBID, BIM, and PUMA initiates mitochondrial apoptosis. Mol Cell 2009; 36 : 487-499.

70. Annis MG, Soucie EL, Dlugosz PJ, Cruz-Aguado JA, Penn LZ, Leber B et al. Bax forms multispanning monomers that oligomerize to permeabilize membranes during apoptosis. EMBO J 2005; 24: 2096-2103.

71. Zhang Z, Subramaniam S, Kale J, Liao C, Huang B, Brahmbhatt $\mathrm{H}$ et al. BH3-in-groove dimerization initiates and helix 9 dimerization expands Bax pore assembly in membranes. EMBO J 2016; 35: 208-236.

72. Mandal T, Shin S, Aluvila S, Chen HC, Grieve C, Choe JY et al. Assembly of Bak homodimers into higher order homooligomers in the mitochondrial apoptotic pore. Sci Rep 2016; 6: 30763.

73. Subburaj Y, Cosentino K, Axmann M, Pedrueza-Villalmanzo E, Hermann E, Bleicken S et al. Bax monomers form dimer units in the membrane that further self-assemble into multiple oligomeric species. Nat Commun 2015; 6: 8042. 
74. Dewson G, Kratina T, Czabotar P, Day CL, Adams JM, Kluck RM. Bak activation for apoptosis involves oligomerization of dimers via their alpha6 helices. Mol Cell 2009; 36: 696-703.

75. Dewson G, Ma S, Frederick P. Hockings C, Tan I, Kratina T et al. Bax dimerizes via a symmetric BH3:groove interface during apoptosis. Cell Death Differ 2012; 19: 661-670.

76. Satsoura D, Kucerka N, Shivakumar S, Pencer J, Griffiths C, Leber B et al. Interaction of the full-length Bax protein with biomimetic mitochondrial liposomes: a small-angle neutron scattering and fluorescence study. Biochim Biophys Acta 2012; 1818: 384-401.

77. Gahl RF, Dwivedi P, Tjandra N. Bcl-2 proteins bid and bax form a network to permeabilize the mitochondria at the onset of apoptosis. Cell Death Dis 2016; 7: e2424.

78. Bleicken S, Classen M, Padmavathi PV, Ishikawa T, Zeth K, Steinhoff HJ et al. Molecular details of Bax activation, oligomerization, and membrane insertion. J Biol Chem 2010; 285 6636-6647.

79. Niu X, Brahmbhatt H, Mergenthaler P, Zhang Z, Sang J, Daude M et al. A small-molecule inhibitor of Bax and Bak oligomerization prevents genotoxic cell death and promotes neuroprotection. Cell Chem Biol 2017; 24: 493-506 e5.

80. Ding J, Mooers BH, Zhang Z, Kale J, Falcone D, McNichol J et al. After embedding in membranes antiapoptotic $\mathrm{Bcl}-\mathrm{XL}$ protein binds both $\mathrm{Bcl}-2$ homology region 3 and helix 1 of proapoptotic Bax protein to inhibit apoptotic mitochondrial permeabilization. J Biol Chem 2014; 289: 11873-11896.

81. Wieckowski MR, Vyssokikh M, Dymkowska D, Antonsson B, Brdiczka D, Wojtczak L. Oligomeric $C$-terminal truncated Bax preferentially releases cytochrome $c$ but not adenylate kinase from mitochondria, outer membrane vesicles and proteoliposomes. FEBS Lett 2001; 505: 453-459.

82. Bleicken S, Landeta O, Landajuela A, Basanez G, Garcia-Saez AJ. Proapoptotic Bax and Bak proteins form stable protein-permeable pores of tunable size. J Biol Chem 2013; 288: 33241-33252.

83. Gillies LA, Du H, Peters B, Knudson CM, Newmeyer DD, Kuwana T. Visual and functional demonstration of growing Bax-induced pores in mitochondrial outer membranes. Mol Biol Cell 2015; 26: 339-349.

84. Salvador-Gallego R, Mund M, Cosentino K, Schneider J, Unsay J, Schraermeyer U et al. Bax assembly into rings and arcs in apoptotic mitochondria is linked to membrane pores. EMBO J 2016; 35: 389-401.

85. Kuwana T, Olson NH, Kiosses WB, Peters B, Newmeyer DD. Pro-apoptotic Bax molecules densely populate the edges of membrane pores. Sci Rep 2016; 6: 27299.

86. Kutuk O, Letai A. Regulation of $\mathrm{Bcl}-2$ family proteins by posttranslational modifications. Curr Mol Med 2008; 8: 102-118.

87. Vantieghem A, Xu Y, Assefa Z, Piette J, Vandenheede JR, Merlevede W et al Phosphorylation of Bcl-2 in G2/M phase-arrested cells following photodynamic therapy with hypericin involves a CDK1-mediated signal and delays the onset of apoptosis. J Biol Chem 2002; 277: 37718-37731

88. Yamamoto $\mathrm{K}$, Ichijo $\mathrm{H}$, Korsmeyer SJ. BCL-2 is phosphorylated and inactivated by an ASK1/Jun N-terminal protein kinase pathway normally activated at G(2)/M. Mol Cell Biol 1999; 19: 8469-8478.

89. Geng F, Tang L, Li Y, Yang L, Choi KS, Kazim AL et al. Allyl isothiocyanate arrests cance cells in mitosis, and mitotic arrest in turn leads to apoptosis via Bcl-2 protein phosphorylation. J Biol Chem 2011; 286: 32259-32267.

90. Deng X, Gao F, Flagg T, May WS Jr. Mono- and multisite phosphorylation enhances Bcl2's antiapoptotic function and inhibition of cell cycle entry functions. Proc Natl Acad Sci USA 2004; 101: 153-158.

91. Deng X, Ruvolo P, Carr B, May WS Jr. Survival function of ERK1/2 as IL-3-activated staurosporine-resistant Bcl2 kinases. Proc Natl Acad Sci USA 2000; 97: 1578-1583.

92. Ruvolo PP, Deng $X$, Carr BK, May WS. A functional role for mitochondrial protein kinase Calpha in Bcl2 phosphorylation and suppression of apoptosis. J Biol Chem 1998; 273: 25436-25442.

93. Linseman DA, Butts BD, Precht TA, Phelps RA, Le SS, Laessig TA et al. Glycogen synthase kinase-3beta phosphorylates Bax and promotes its mitochondrial localization during neuronal apoptosis. J Neurosci 2004; 24: 9993-10002.

94. Gardai SJ, Hildeman DA, Frankel SK, Whitlock BB, Frasch SC, Borregaard N et al. Phosphorylation of Bax Ser(184) by Akt regulates its activity and apoptosis in neutrophils. J Biol Chem 2004; 279: 21085-21095.

95. Li R, Moudgil T, Ross HJ, Hu HM. Apoptosis of non-small-cell lung cancer cell lines after paclitaxel treatment involves the BH3-only proapoptotic protein Bim. Cell Death Differ 2005 12: 292-303.

96. Puthalakath H, Villunger A, O'Reilly LA, Beaumont JG, Coultas L, Cheney RE et al. Bmf: a proapoptotic $\mathrm{BH}$-only protein regulated by interaction with the myosin $\mathrm{V}$ actin motor complex, activated by anoikis. Science 2001; 293: 1829-1832.

97. Leber B, Geng F, Kale J, Andrews DW. Drugs targeting Bcl-2 family members as an emerging strategy in cancer. Expert Rev Mol Med 2010; 12: e28.

98. Lewis A, Hayashi T, Su TP, Betenbaugh MJ. Bcl-2 family in inter-organelle modulation of calcium signaling; roles in bioenergetics and cell survival. J Bioenerg Biomembr 2014; 46 : $1-15$.
99. Monaco G, Vervliet T, Akl H, Bultynck G. The selective BH4-domain biology of Bcl-2-family members: IP3Rs and beyond. Cell Mol Life Sci 2013; 70: 1171-1183.

100. Williams A, Hayashi T, Wolozny D, Yin B, Su TC, Betenbaugh MJ et al. The non-apoptotic action of $\mathrm{Bcl}-\mathrm{xL}$ : regulating $\mathrm{Ca}(2+)$ signaling and bioenergetics at the ER-mitochondrion interface. J Bioenerg Biomembr 2016; 48: 211-225.

101. Li C, Wang X, Vais H, Thompson CB, Foskett JK, White C. Apoptosis regulation by Bcl-x(L) modulation of mammalian inositol 1,4,5-trisphosphate receptor channel isoform gating. Proc Natl Acad Sci USA 2007; 104: 12565-12570.

102. Scorrano L, Oakes SA, Opferman JT, Cheng EH, Sorcinelli MD, Pozzan T et al. BAX and BAK regulation of endoplasmic reticulum $\mathrm{Ca2+:}$ a control point for apoptosis. Science 2003; 300: $135-139$.

103. Chami M, Prandini A, Campanella M, Pinton P, Szabadkai G, Reed JC et al. Bcl-2 and Bax exert opposing effects on $\mathrm{Ca} 2+$ signaling, which do not depend on their putative poreforming region. J Biol Chem 2004; 279: 54581-54589.

104. Certo M, Del Gaizo Moore V, Nishino M, Wei G, Korsmeyer S, Armstrong SA et al. Mitochondria primed by death signals determine cellular addiction to antiapoptotic BCL-2 family members. Cancer Cell 2006; 9: 351-365.

105. Del Gaizo Moore V, Letai A. BH3 profiling-measuring integrated function of the mitochondrial apoptotic pathway to predict cell fate decisions. Cancer Lett 2013; 332: 202-205.

106. Leber B, Lin J, Andrews DW. Still embedded together binding to membranes regulates Bcl2 protein interactions. Oncogene 2010; 29: 5221-5230.

107. Tse C, Shoemaker AR, Adickes J, Anderson MG, Chen J, Jin S et al. ABT-263: a potent and orally bioavailable $\mathrm{Bcl}-2$ family inhibitor. Cancer Res 2008; 68: 3421-3428.

108. Souers AJ, Leverson JD, Boghaert ER, Ackler SL, Catron ND, Chen J et al. ABT-199, a potent and selective BCL-2 inhibitor, achieves antitumor activity while sparing platelets. Nat Med 2013; 19: 202-208

109. Delbridge AR, Grabow S, Strasser A, Vaux DL. Thirty years of BCL-2: translating cell death discoveries into novel cancer therapies. Nat Rev Cancer 2016; 16: 99-109.

110. Grabow S, Delbridge AR, Valente LJ, Strasser A. MCL-1 but not BCL-XL is critical for the development and sustained expansion of thymic lymphoma in p53-deficient mice. Blood 2014; 124: 3939-3946.

111. Zhang $H$, Guttikonda S, Roberts L, Uziel T, Semizarov D, Elmore SW et al. Mcl-1 is critical for survival in a subgroup of non-small-cell lung cancer cell lines. Oncogene 2011; 30: 1963-1968.

112. Xiang Z, Luo H, Payton JE, Cain J, Ley TJ, Opferman JT et al. Mcl1 haploinsufficiency protects mice from Myc-induced acute myeloid leukemia. J Clin Invest 2010; 120: 2109-2118.

113. Yecies D, Carlson NE, Deng J, Letai A. Acquired resistance to ABT-737 in lymphoma cells that up-regulate MCL-1 and BFL-1. Blood 2010; 115: 3304-3313.

114. Kotschy A, Szlavik Z, Murray J, Davidson J, Maragno AL, Le Toumelin-Braizat G et al. The MCL1 inhibitor S63845 is tolerable and effective in diverse cancer models. Nature 2016; 538: 477-482.

115. Liu Q, Leber B, Andrews DW. Interactions of pro-apoptotic BH3 proteins with anti-apoptotic Bcl-2 family proteins measured in live MCF-7 cells using FLIM FRET. Cell Cycle 2012; 11: 3536-3542.

116. Aranovich A, Liu Q, Collins T, Geng F, Dixit S, Leber B et al. Differences in the mechanisms of proapoptotic $\mathrm{BH} 3$ proteins binding to $\mathrm{Bcl}-\mathrm{XL}$ and $\mathrm{Bcl}-2$ quantified in live MCF-7 cells. $\mathrm{Mol}$ Cell 2012; 45: 754-763.

117. Pecot J, Maillet L, Le Pen J, Vuillier C, Trecesson SC, Fetiveau A et al. Tight Sequestration of $\mathrm{BH} 3$ Proteins by BCL-xL at Subcellular Membranes Contributes to Apoptotic Resistance. Cell Rep 2016; 17: 3347-3358.

118. Lopez CF, Muhlich JL, Bachman JA, Sorger PK. Programming biological models in Python using PySB. Mol Syst Biol 2013; 9: 646.

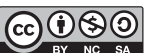

This work is licensed under a Creative Commons Attribution-NonCommercial-ShareAlike 4.0 International License. The images or other third party material in this article are included in the article's Creative Commons license, unless indicated otherwise in the credit line; if the material is not included under the Creative Commons license, users will need to obtain permission from the license holder to reproduce the material. To view a copy of this license, visit http://creativecommons.org/licenses/by-nc-sa/4.0/

(C) The Author(s) 2018 